\title{
əInterannual to Decadal Variability of Upper-Ocean Salinity in the Southern Indian Ocean and the Role of the Indonesian Throughflow
}

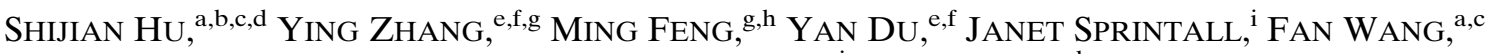 \\ DUNXIN Hu, ${ }^{\mathrm{a}, \mathrm{c}}$ QIANG XIE, ${ }^{\mathrm{e}, \mathrm{j}}$ AND FEI ChaI ${ }^{\mathrm{b}}$ \\ ${ }^{a}$ Chinese Academy of Sciences Key Laboratory of Ocean Circulation and Waves, Institute of Oceanology, \\ Center for Ocean Mega-Science, Chinese Academy of Sciences, Qingdao, China \\ ${ }^{\mathrm{b}}$ State Key Laboratory of Satellite Ocean Environment Dynamics, Second Institute of Oceanography, \\ State Oceanic Administration, Hangzhou, China \\ ${ }^{\mathrm{c}}$ Pilot National Laboratory for Marine Science and Technology (Qingdao), Qingdao, China \\ ${ }^{\mathrm{d}}$ College of Marine Science, University of Chinese Academy of Sciences, Qingdao, China \\ ${ }^{\text {e }}$ State Key Laboratory of Tropical Oceanography, South China Sea Institute of Oceanology, \\ Chinese Academy of Sciences, Guangzhou, China \\ ${ }^{\mathrm{f}}$ University of Chinese Academy of Sciences, Beijing, China \\ ${ }^{\mathrm{g}}$ CSIRO Oceans and Atmosphere, Crawley, Western Australia, Australia \\ ${ }^{\mathrm{h}}$ Centre for Southern Hemisphere Oceans Research, CSIRO Oceans and Atmosphere, Hobart, Tasmania, Australia \\ ${ }^{i}$ Scripps Institution of Oceanography, University of California San Diego, La Jolla, California \\ ${ }^{\mathrm{j}}$ Institute of Deep-Sea Science and Engineering, Chinese Academy of Sciences, Sanya, China
}

(Manuscript received 22 January 2019, in final form 23 June 2019)

\begin{abstract}
Variability of oceanic salinity, an indicator of the global hydrological cycle, plays an important role in the basin-scale ocean circulation. In this study, interannual to decadal variability of salinity in the upper layer of the Indian Ocean is investigated using Argo observations since 2004 and data assimilating model outputs (19922015). The southeastern Indian Ocean shows the strongest interannual to decadal variability of upper-ocean salinity in the Indian Ocean. Westward propagation of salinity anomalies along isopycnal surfaces is detected in the southern Indian Ocean and attributed to zonal salinity advection anomalies associated with the Indonesian Throughflow and the South Equatorial Current. Composite and salinity budget analyses show that horizontal advection is a major contributor to the interannual to decadal salinity variability of the southern Indian Ocean, and the local air-sea freshwater flux plays a secondary role. The Pacific decadal oscillation (PDO) and El NiñoSouthern Oscillation (ENSO) modulate the salinity variability in the southeastern Indian Ocean, with low salinity anomalies occurring during the negative phases of the PDO and ENSO and high salinity anomalies during their positive phases. The Indonesian Throughflow plays an essential role in transmitting the PDO- and ENSO-related salinity signals into the Indian Ocean. A statistical model is proposed based on the PDO index, which successfully predicts the southeastern Indian Ocean salinity variability with a lead time of 10 months.
\end{abstract}

\section{Introduction}

Oceanic salinity plays an important role in the climate system due to its significant influence on oceanic stratification and barrier layers (Sprintall and Tomczak

D Denotes content that is immediately available upon publication as open access.

Shijian $\mathrm{Hu}$ and Ying Zhang contributed equally to this work.

Corresponding author: Ming Feng, ming.feng@csiro.au
1992; Thompson et al. 2006; Balaguru et al. 2016) and ocean circulation (Gordon et al. 2003; Feng et al. 2015; $\mathrm{Hu}$ and Sprintall 2016, 2017a,b), and has a close link to the global hydrological cycle (Durack and Wijffels 2010; Durack et al. 2012). Investigation of ocean salinity variability and underlying dynamics is hence of essential significance for better understanding and prediction of the ocean and climate system.

The Indian Ocean plays a key role in the global thermohaline circulation and climate system. Uniquely in comparison to other ocean basins, the Indian Ocean is blocked at about $25^{\circ} \mathrm{N}$ by the Asian landmass and is subject to significant interbasin exchanges of heat and 
freshwater through the Indonesian Throughflow (ITF; Gordon 2001) and the Agulhas Current system (de Ruijter et al. 1999). Freshwater balance and salinity variability in the Indian Ocean hence have attracted broad interest from the oceanography and climate community (e.g., Piola and Gordon 1984; Han and McCreary 2001; Rao and Sivakumar 2003; Drushka et al. 2014; Giglio and Roemmich 2014; Llovel and Lee 2015; Jensen et al. 2016; Nyadjro and Subrahmanyam 2016; Kido and Tozuka 2017).

Numerical experiments with a simple advective box model suggested that the ITF and atmospheric freshwater input are important to the salinity balance in the Indian Ocean, with a $14-\mathrm{Sv}\left(1 \mathrm{~Sv} \equiv 10^{6} \mathrm{~m}^{3} \mathrm{~s}^{-1}\right)$ transport of $33.6 \%$ salinity input required for the freshwater balance of the Indian Ocean (Piola and Gordon 1984). Input from river inflow and the ITF are essential to reproduce the observed salinity distribution in the Indian Ocean as shown by model experiments (Han and McCreary 2001). The ITF tends to lower the Indian Ocean salinities and most of the ITF waters eventually flow out of the Indian Ocean along the western boundary through the Agulhas Current (Han and McCreary 2001). Song et al. (2004) examined the spreading pathways and time scales of the ITF waters in the Indian Ocean, and their Lagrangian trajectory experiment suggested that the ITF waters in the upper thermocline take about 10 years to transit from the Makassar Strait to the east coast of the African continent.

On seasonal time scales, freshwater input due to rainfall and river discharge is important to the salinity balance in the Bay of Bengal, while horizontal advection related to the monsoon plays a dominant role in the north Indian Ocean (Rao and Sivakumar 2003). In the tropical Indian Ocean, the seasonal cycle of the mixed layer salinity in the south-central Arabian Sea is mainly due to meridional advection driven by the monsoon winds, while freshwater flux due to precipitation may play an important role in the southwestern tropical Indian Ocean (Da-Allada et al. 2015). Seasonality of the mixed layer salinity in the southeastern tropical Indian Ocean is influenced by the annual cycles of the ITF and the Leeuwin Current transports, air-sea freshwater forcing, and eddy fluxes (Zhang et al. 2016). Strong salinity fronts observed within the equatorial region show meridional migration associated with the intertropical convergence zone and meridional ocean currents, which may be modulated interannually by zonal advections of less saline waters from the eastern Indian Ocean related to the ITF (Nyadjro and Subrahmanyam 2016). Salinity and barrier-layer thickness in the eastern equatorial Indian Ocean show energetic subseasonal variation related to the Madden-Julian oscillations (Drushka et al. 2014; Li et al. 2015).

In the northern Indian Ocean, interannual variability of the Wyrtki jet and Bay of Bengal circulation exerts significant influence on salinity anomalies through freshwater exchange between the Bay of Bengal and the rest of the equatorial Indian Ocean that may be influenced by the Indian Ocean dipole (IOD) (Thompson et al. 2006). In the equatorial Indian Ocean, significant interannual variability of salinity associated with the IOD mode in the boreal fall is mainly due to zonal advection. Low-salinity water is advected westward during the mature phase of the positive IOD (pIOD) and advected across the equator to the southwestern Indian Ocean during the decay phase of the pIOD. However, when the pIOD occurs concurrently with an El Niño event, poleward advection occurs after the decay phase due to the strengthened off-equatorial anticyclonic circulation (Zhang et al. 2013). In the southeast Indian Ocean, interannual variability of the mixed layer salinity is influenced by the El Niño-Southern Oscillation (ENSO) cycle through modulation in both advection and local precipitation (Zhang et al. 2016). Salinity anomalies due to ENSO-related precipitation change within the Indonesian seas are found to propagate along the major ITF pathway and cause interannual variability of upper-layer salinity in the ITF outflow region in the eastern Indian Ocean ( $\mathrm{Hu}$ and Sprintall 2016). Salinity anomalies on the isopycnals $24-26 \sigma_{\theta}$ in the south Indian Ocean during 2004-15 were proposed to be induced by surface freshwater fluxes in the isopycnal outcropping regions in the southeastern Indian Ocean associated with the warm surge along the Western Australia coastline known as Ningaloo Niño (e.g., Feng et al. 2013; 2015) and with ENSO (Nagura and Kouketsu 2018).

Significant freshening events in the Indian Ocean have been observed on interannual to decadal time scales. Phillips et al. (2005) found that the freshening in the eastern Indian Ocean from 1999 to 2002 was induced by surface freshwater flux over the Indonesian seas with stronger ITF advection associated with a long-lasting La Niña event. Local precipitation and the ITF transport lead to interannual freshening events in the southern Indian Ocean and further cause an increase of the Leeuwin Current transport (e.g., Zhang et al. 2016; Feng et al. 2015). Kido and Tozuka (2017) investigated interannual salinity variability in the central-eastern equatorial and southeastern tropical Indian Ocean and found that subsurface salinity anomalies are mainly caused by anomalous zonal and vertical advections associated with the pIOD.

The basinwide salinity structure in the Indian Ocean also shows decadal variability (e.g., Han et al. 2014). 
Salinity observations in the Indian Ocean at about $32^{\circ} \mathrm{S}$ imply a freshening in the Southern Ocean and intensification of the global hydrological cycle from the 1960 s to the 1980s (Wong et al. 1999). Durack and Wijffels (2010) found significant multidecadal trends in salinity down to 2000-dbar depth during 1950-80. They suggested that the ocean's mean flow of surface salinity and temperature anomalies account for most regional subsurface salinity changes on isopycnal surfaces (Durack and Wijffels 2010). In the upper 300-m layer of the southeast Indian Ocean, observations show a freshening during 2005-13 that gave rise to a large halosteric contribution to regional sea level rise (Llovel and Lee 2015).

Idealized model experiments suggest that multidecadal changes of subsurface ocean salinity during 1950-2000 were a result of an amplification of the mean surface salinity pattern and isopycnal migration due to the ocean surface warming (Lago et al. 2016). However, the enhanced precipitation in the Maritime Continent and the strengthening of the ITF are thought to be the likely causes of the freshening trend in the southeast Indian Ocean since early 2000s, rather than local Ekman pumping and freshwater flux anomalies (Llovel and Lee 2015; $\mathrm{Hu}$ and Sprintall 2017a,b). The enhanced precipitation in the Maritime Continent is thought to strengthen the ITF due to a salinity effect that influences the large-scale sea surface height variability $(\mathrm{Hu}$ and Sprintall 2017a). Du et al. (2015) noted a contrasting sea surface salinity (SSS) trend pattern characterized by freshening in the southeastern tropical Indian Ocean and salinification in the western tropical Pacific starting in the mid-1990s, which is attributed to a strengthening trend of the Indo-Pacific Walker circulation combined with ocean advection processes.

Salinity satellites were launched recently to observe the SSS from space, for example, the Soil Moisture and Ocean Salinity (SMOS; Kerr et al. 2001), the Soil Moisture Active Passive (Entekhabi et al. 2010), and Aquarius (Lagerloef et al. 2008) satellites. Satellite salinity observations have led to numerous studies of SSS variability (e.g., a special issue on "Early scientific results from the salinity measuring satellites Aquarius/ SAC-D and SMOS" published by the Journal of Geophysical Research: Oceans in 2014; Felton et al. 2014; Menezes et al. 2014; Moon and Song 2014; Vinogradova et al. 2019). For instance, Gordon et al. (2015) described the subtropical surface salinity patterns with an emphasis on the SSS maxima. Still, salinity variability at depth (e.g., in the thermocline layer) may possess different features and variability compared to SSS.

Previous studies have greatly improved our understanding of salinity processes in the Indian Ocean.
However, the characteristics and dynamics of the Indian Ocean salinity processes related to interannual and decadal climate modes [e.g., the Pacific decadal oscillation (PDO) and ENSO], especially isopycnal salinity processes at depths, have not yet been fully quantified. Potential predictability of interannual to decadal variability of salinity in the Indian Ocean is also unknown. Subsurface salinity observations have sharply accumulated since the early 2000 s with the implementation of the Argo program (Roemmich et al. 1998) and enhancement of the tropical mooring arrays and cruises (McPhaden et al. 2009; Hu et al. 2011; Ando et al. 2017), in conjunction with the twenty-first-century launch of satellites to measure SSS. Two decades of salinity observations in the Indian Ocean and state-of-the-art numerical model simulations provide a valuable opportunity for the present study to examine the characteristics and dynamics of interannual to decadal salinity variability in the Indian Ocean.

The remainder of this paper is arranged as follows. Section 2 describes the data and methods. Temporal and spatial features and zonal propagation of salinity signals along isopycnal surfaces in the Indian Ocean are presented in sections $3 a$ and $3 b$, respectively. Dynamics controlling the observed interannual to decadal variability of salinity in the Indian Ocean are examined through a composite analysis and a salinity budget analysis in section 3c. Section 4 investigates the relationship between the Indian Ocean salinity and climate modes on interannual to decadal time scales. Section 5 discusses the uncertainty and shows a comparison of sea surface salinity variations between Argo and satellite observations. Section 6 summarizes the results and discusses the remaining issues.

\section{Data and methods}

We use the gridded Argo dataset and numerical assimilations from Estimating the Circulation and Climate of the Ocean (ECCO) in this study. The gridded Argo Climatology (RG Argo Climatology; Roemmich and Gilson 2009) consists of monthly mean horizontally and vertically mapped temperature and salinity fields estimated using a weighted least squares fit to Argo profiles during 2004-17. The RG Argo Climatology has a resolution of $1^{\circ} \times 1^{\circ}$ horizontally and is available on standard depths with $O(10) \mathrm{m}$ resolution in the upper $100 \mathrm{~m}$ and coarser below. We will discuss the uncertainty of RG Argo Climatology and Argo profile data in section 6. Argo float vertical profiling data (2004-17) are used to discuss the potential uncertainties within the Argo profile data and the RG Argo Climatology (Wong et al. 2019). 
The ECCO version 4 release 3 (ECCO v4.3) estimate, produced by the Massachusetts Institute of Technology General Circulation Model (MITgcm; Marshall et al. 1997a,b), is global (including the Arctic Ocean) with 50 vertical layers and a spatially varying resolution of $1^{\circ}$ longitude and $1 / 3^{\circ}-1^{\circ}$ latitude covering the 1992-2015 period. ECCO v 4.3 is forced by an adjusted version of the ERA-Interim atmospheric reanalysis (Dee et al. 2011) and synthesizes almost all available ocean observations (e.g., satellites, expendable bathythermographs, Argo floats, etc.), including Aquarius and AVHRR satellite surface salinity/temperature data by least squares fitting of the MITgcm (Fukumori et al. 2017; Forget et al. 2016; Forget et al. 2015; Wunsch et al. 2009; Wunsch and Heimbach 2007). The adjoint-based ECCO satisfies the equations of motion and conservation laws without artificial internal heat and freshwater sources/sinks (Wunsch and Heimbach 2013), thus ECCO is a dynamically and kinematically consistent state estimate. This feature enables term-by-term diagnostics of the salinity budget to explore the dynamic mechanisms of salinity changes.

Monthly precipitation from the Global Precipitation Climatology Project (GPCP; Adler et al. 2003) and evaporation from the Objectively Analyzed Air-Sea Fluxes (OAFlux; Yu et al. 2008) are used to calculate surface freshwater flux (evaporation minus precipitation, $E-P$ ). Wind stress from the NOAA Environmental Research Division's Data Access Program (ERDDAP) and sea level anomaly (SLA) from the AVISO are used to examine the related surface forcing. Monthly SSS data based on satellite observations from the SMAP (version 4.1; Entekhabi et al. 2010) are used to compare the surface salinity from Argo (2.5 dbar).

The salinity budget is formulated as

$$
\frac{\partial[S]}{\partial t}=\operatorname{Adv}_{x}+F_{s}+\operatorname{Res},
$$

where

$$
\begin{aligned}
\operatorname{Adv}_{x} & =\frac{1}{V} \int_{A}(\mathbf{V} \cdot \mathbf{n})(S-[S]) d A, \\
F_{s} & =[S] \frac{\iint_{A}(E-P) d A}{V},
\end{aligned}
$$

and

$$
[S]=\frac{\iiint_{V} S d V}{V} .
$$

Here $S$ is salinity and $t$ is the time; $V$ and $A$ are respectively the volume and surface area of the domain; $F_{S}$ is surface forcing, defined as the difference between evaporation and precipitation $(E-P$, referred to as sea surface freshwater flux). Also, $\operatorname{Adv}_{x}$ is the salinity advection across the boundaries $x$ : the $x$ boundaries include four horizontal open-ocean boundaries of the control volume at $80^{\circ} \mathrm{E}\left(\mathrm{Adv}_{w}\right.$, western boundary), $115^{\circ} \mathrm{E}\left(\mathrm{Adv}_{e}\right.$, eastern boundary), $5^{\circ} \mathrm{S}\left(\mathrm{Adv}_{n}\right.$, northern boundary), $32^{\circ} \mathrm{S}\left(\mathrm{Adv}_{s}\right.$, southern boundary), and the bottom boundary of the control volume at the depth of $400 \mathrm{~m}\left(\mathrm{Adv}_{r}\right)$. The expression $\mathbf{V} \cdot \mathbf{n}$ is normal velocity, including zonal $(u)$, meridional $(v)$, and vertical $(w)$ velocities. Res represents residuals, which include the horizontal and vertical diffusion, all other unresolved horizontal and vertical processes, and computational errors. Here $[S]$ is the time variable but space-averaged salinity within the control volume; $[S]$ is used as the reference salinity for the salinity advection. By including $[S]$ in the salinity advection terms in (2), the external advection mechanisms that influence the spatially averaged salinity of the domain, including boundary processes, are quantified. This method was introduced by Lee et al. (2004) and has been widely used in heat balance analyses (e.g., Feng et al. 2008; Guan and McPhaden 2016; Zhang et al. 2018). Critically, for our purposes it enables us to differentiate between the internal and external sources/sinks.

We adopt the PDO index computed using ERSST (version 4) following the Mantua PDO index. The Niño3.4 index is defined as the 3-month running mean of SST anomalies in the tropical Pacific $\left(5^{\circ} \mathrm{N}-5^{\circ} \mathrm{S}\right.$ and $120^{\circ}$ $\left.170^{\circ} \mathrm{W}\right)$. The dipole mode index (DMI), which describes the intensity of the IOD, is defined as anomalous SST gradient between $50^{\circ}-70^{\circ} \mathrm{E}, 10^{\circ} \mathrm{S}-10^{\circ} \mathrm{N}$ and $90^{\circ}-110^{\circ} \mathrm{E}$, $10^{\circ} \mathrm{S}-0^{\circ} \mathrm{N}$ (Saji et al. 1999).

\section{Results}

\section{a. Temporal and spatial features}

Figure 1 shows a climatological map of vertical mean (0-400 dbar) salinity and sea surface freshwater flux $(E-P)$ over 2004-17. The spatial pattern of salinity is in general agreement with that of the sea surface freshwater flux. The tropical Indian Ocean, particularly the tropical eastern Indian Ocean, shows lower salinity due to a stronger freshwater input at the sea surface. However, a sizeable freshwater pool is observed in the Indonesian-Australian basin of the tropical southeastern Indian Ocean, even though $E-P$ is positive and the ocean loses freshwater at the surface. The freshwater pool is a result of significant freshwater transport by the ITF from the Indonesian seas (e.g., Phillips et al. 2005). Therefore, both sea surface freshwater flux and ocean 


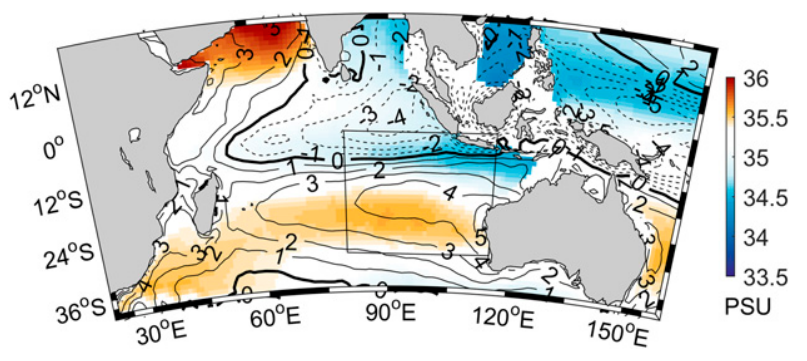

FIG. 1. Observed vertical mean salinity in the upper 400-dbar layer (color; psu) from the RG Argo and $E-P$ (contour lines; mm day ${ }^{-1}$ ) in the Indian Ocean. Both salinity and $E-P$ are averaged over 2004 17. The black box denotes the region for the salinity budget analysis.

dynamics are essential in forming the mean salinity pattern of the Indian Ocean.

The Indian Ocean shows significant interannual to decadal variability but its spatial pattern is quite different from annual or higher-frequency variability. Seasonality of salinity in the northern Indian Ocean basin is mainly due to monsoon-related dynamics (e.g., Rao and Sivakumar 2003). However, on interannual to decadal time scales, salinity variability mostly occurs in the tropical to subtropical southeastern Indian Ocean (Fig. 2). Interannual to decadal variability of $0-400-\mathrm{m}$ mean salinity has standard deviations greater than 0.04 psu in the southeastern Indian Ocean and constitutes about $50 \%-80 \%$ of the total salinity variance. Hence, interannual to decadal variability is a major component of the Indian Ocean salinity variability and the southeastern Indian Ocean is a key region in understanding interannual to decadal salinity variability of the whole Indian Ocean basin.

To investigate interannual to decadal salinity variability in the southern Indian Ocean, we calculated area mean salinity anomalies $S^{\prime}$ and potential density $\sigma_{\theta}$ in three boxes, $110^{\circ}-116^{\circ} \mathrm{E}, 12^{\circ}-18^{\circ} \mathrm{S} ; 77^{\circ}-83^{\circ} \mathrm{E}, 12^{\circ}-18^{\circ} \mathrm{S}$; and $52^{\circ}-58^{\circ} \mathrm{E}, 12^{\circ}-18^{\circ} \mathrm{S}$, which represent the southeastern, south central, and southwestern Indian Oceans, respectively. Salinity and potential density are from the RG-Argo (Fig. 3) and ECCO datasets (Fig. 4).

The Argo observations indicate that upper-layer salinity anomalies in the three boxes tend to have a phase change: positive in the first half of the Argo era (roughly 2004-10) and more negative anomalies in the remainder of the Argo era (Fig. 3). Salinity in the western box shows a weaker interannual to decadal variability than the eastern and central boxes. Standard deviations of upper 400-m-layer mean salinity in the three boxes from west to east are about $0.02,0.04$, and 0.03 psu, respectively. Variation of the vertical mean salinity anomaly is between about \pm 0.05 psu, implying a decadal change of about $0.1 \mathrm{psu}$. The vertical structure of $S^{\prime}$
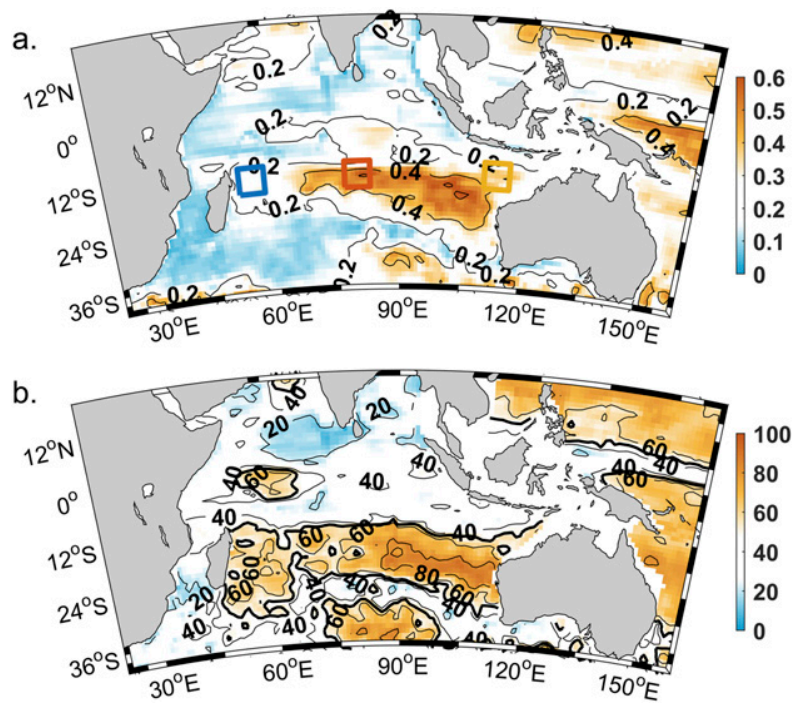

FIG. 2. (a) Standard deviation (STD) of upper 400-dbar mean RG Argo salinity $\left(10^{-1} \mathrm{psu}\right)$ that is smoothed twice by a 13 -month running mean filter. (b) Percentage (\%) of STD of the 13-month running mean salinity over that of monthly nonfiltered salinity. Thick black contour lines in the bottom panel indicate $50 \%$. Three boxes $\left(110^{\circ}-116^{\circ} \mathrm{E}, 12^{\circ}-18^{\circ} \mathrm{S} ; 77^{\circ}-83^{\circ} \mathrm{E}, 12^{\circ}-18^{\circ} \mathrm{S}\right.$; and $52^{\circ}-58^{\circ} \mathrm{E}$, $12^{\circ}-18^{\circ} \mathrm{S}$ ) in (a) are used to compute regional mean salinity anomalies shown in Fig. 3.

indicates that the variations are mainly confined to the upper ocean, particularly above the isopycnal surface $\sigma_{\theta}=25.5 \mathrm{~kg} \mathrm{~m}^{-3}$. For the central and eastern boxes, upper-layer salinity shows a freshening tendency occurring over 2007-12 with a salinification tendency during the rest of the period (a freshening tendency period has $\left.\partial S^{\prime} / \partial t<0\right)$.

Comparison between Argo and ECCO fields shows general agreement of the interannual to decadal variability of southern Indian Ocean salinity in terms of amplitude and phase (Figs. 3 and 4). ECCO additionally shows that the southeastern Indian Ocean experienced phases of positive salinity anomalies during 1992-98 and 2002-10 and negative phases during 1998-2002 and 2010-15, in agreement with previous observations (Phillips et al. 2005; Zhang et al. 2016).

Salinity anomalies in the southwestern (Figs. 3c and 4c) and south central (Figs. 3b and 4b) Indian Ocean have interannual to decadal phases similar to those in the southeastern (Figs. 3a and 4a) Indian Ocean, but with phase lags: the eastern box leads the central box, which then leads the western box. The phase lags between the three regions imply westward propagation of salinity anomalies in the southern Indian Ocean. This will be discussed in detail in section 3b. Salinity variation contributes to about $29 \%-50 \%$ of the total variation in vertical mean potential density (Figs. 3 and 4 and Table 1). 

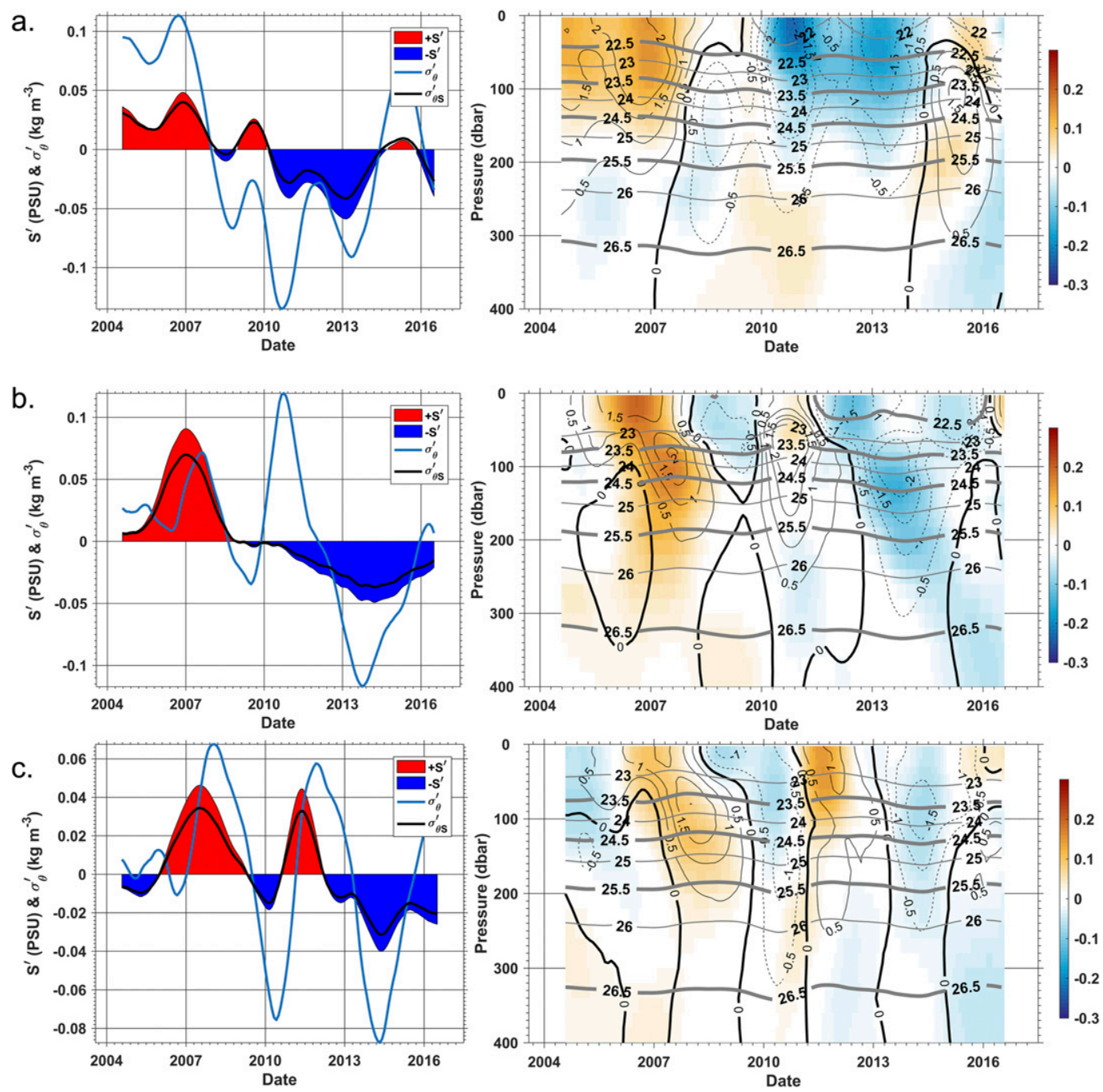

FIG. 3. (left) Time series of area mean salinity anomaly $S^{\prime}(\mathrm{psu})$, potential density anomaly $\sigma_{\theta}^{\prime}$ relative to the temporal mean during 2004-17 averaged over the upper 400 dbar, and potential density anomaly due to salinity variations $\sigma_{\theta S}^{\prime}$, and (right) vertical profiles of $S^{\prime}$ (color; psu), $\sigma_{\theta}^{\prime}$ (black contour lines; $\mathrm{kg} \mathrm{m}^{-3}$ ), and $\sigma_{\theta}$ (gray contours; $\left.\mathrm{kg} \mathrm{m}^{-3}\right)$ averaged within the (a) southeastern $\left(110^{\circ}-116^{\circ} \mathrm{E}, 12^{\circ}-18^{\circ} \mathrm{S}\right)$, (b) south central $\left(77^{\circ}-83^{\circ} \mathrm{E}, 12^{\circ}-18^{\circ} \mathrm{S}\right)$, and (c) southwestern $\left(52^{\circ}-58^{\circ} \mathrm{E}, 12^{\circ}-18^{\circ} \mathrm{S}\right)$ Indian Ocean (see Fig. 2a for box locations). Results are from the RG Argo.

The phase change of ocean salinity from positive to negative during the Argo era indicates a significant freshening trend in the tropical to subtropical southeastern Indian Ocean. Over 2004-17, the southeastern Indian Ocean from about $12^{\circ}$ to $32^{\circ} \mathrm{S}$ and ranging from the eastern boundary to about $60^{\circ} \mathrm{E}$ is dominated by a freshening trend, while a salinification trend extends from the Southern Ocean to about $32^{\circ} \mathrm{S}$ (Fig. 5a).

The decadal variability of Indian Ocean salinity is mainly confined to the southeastern Indian Ocean ranging from the eastern boundary to about $60^{\circ} \mathrm{E}$ (Fig. 5). The spatial pattern of the linear trend in the upper-layer salinity (Fig. 5a) is quite similar to that of the composited decadal salinity anomalies constructed from the freshening period (January 2011-December 2017) minus the salinification period (January 2004December 2010) (Fig. 5b). The salinity trend is greater than 0.04 psu decade ${ }^{-1}$ (statistically significant at $99 \%$ confidence level), up to 0.16 psu decade ${ }^{-1}$ (Figs. 5a,b). Regionally, Phillips et al. (2005) reported a significant freshening event in the southeastern Indian Ocean (east of $100^{\circ} \mathrm{E}$ ), which had an average anomaly of 0.2 psu relative to the CSIRO Atlas of Regional Seas, that persisted over the period from 1999 to 2002 and was probably related to the 1999-2000 La Niña. The freshening contributes to a significant decrease in the vertical 

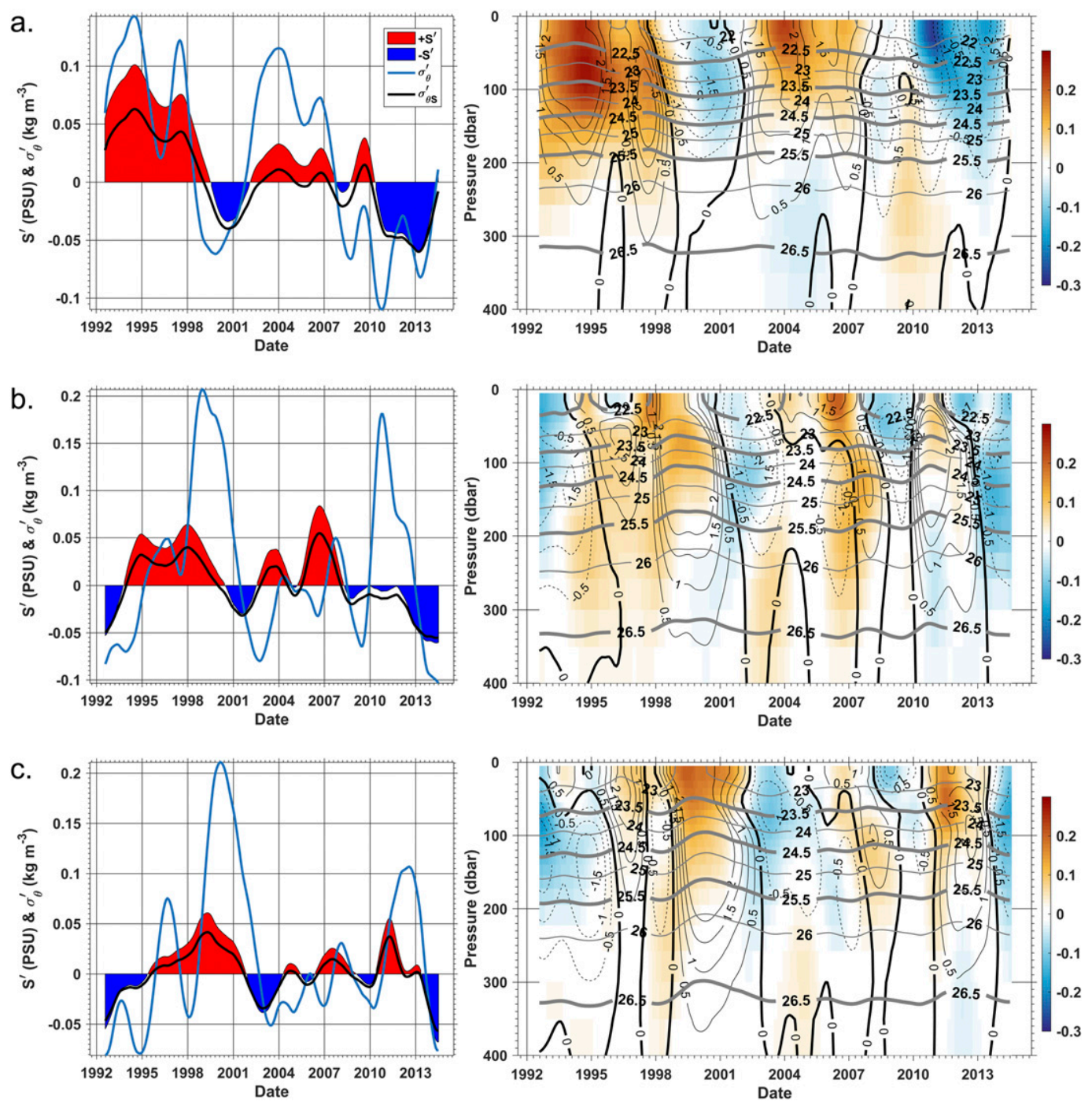

FIG. 4. As in Fig. 3, but for the ECCO assimilations.

mean potential density $\sigma_{\theta}$ of up to $-0.12 \mathrm{~kg} \mathrm{~m}^{-3}$ (Fig. 5b).

\section{b. Propagation of salinity signals along isopycnals}

As mentioned above, salinity signals may be advected westward in the southern Indian Ocean. To examine this phenomenon, we plot Hovmöller diagrams of salinity anomalies using both Argo and ECCO datasets on various isopycnal surfaces: $\sigma_{\theta}=23,24,25$, and $26 \mathrm{~kg} \mathrm{~m}^{-3}$ along $15^{\circ} \mathrm{S}$ (Fig. 6) where the salinity signals extend farthest west into the Indian Ocean (see Fig. 5).

TABLE 1. Comparison of density variation $\left(\mathrm{kg} \mathrm{m}^{-3}\right)$ and that induced by salinity change. Note that STD $\sigma$ is the standard deviation of the vertical mean potential density anomaly shown in the left panels of Figs. 3 and 4; STD $\sigma_{S}$ is the standard deviation of the salinity-induced potential density anomaly shown in black lines in the left panels of Figs. 3 and 4 . Salinity contribution is defined as $\left(\mathrm{STD} \sigma_{S} / \mathrm{STD} \sigma\right) \times$ $100 \%$.

\begin{tabular}{|c|c|c|c|c|c|c|}
\hline & \multicolumn{3}{|c|}{ Argo } & \multicolumn{3}{|c|}{ ECCO } \\
\hline & Southwestern & South central & Southeastern & Southwestern & South central & Southeastern \\
\hline $\operatorname{STD} \sigma$ & 0.02 & 0.03 & 0.02 & 0.02 & 0.03 & 0.03 \\
\hline $\mathrm{STD} \sigma_{S}$ & 0.04 & 0.06 & 0.07 & 0.07 & 0.08 & 0.07 \\
\hline $\begin{array}{l}\text { Salinity } \\
\quad \text { contribution (\%) }\end{array}$ & 50 & 50 & 29 & 29 & 38 & 43 \\
\hline
\end{tabular}




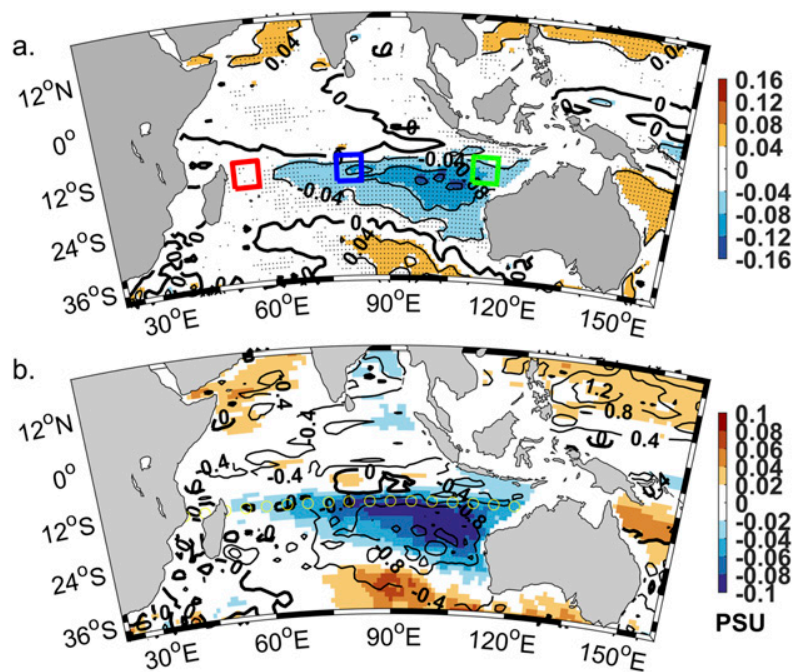

FIG. 5. (a) Linear trends of vertical mean salinity (psu decade ${ }^{-1}$ ) in the upper 400-dbar Indian Ocean from RG Argo during 200417. The area with confidence level greater than $99.9 \%$ is highlighted by black dots. (b) Composited salinity (color; psu) and $\sigma_{\theta}$ (contour lines; $10^{-1} \mathrm{~kg} \mathrm{~m}^{-3}$ ) anomalies over January 2011December 2017 minus those composited over January 2004December 2010. Yellow circles in (b) denote the path along $15^{\circ} \mathrm{S}$. Three boxes are shown as in Fig. 2a.

Salinity anomalies along isopycnal surfaces show welldefined decadal variability and clear westward propagation. Positive decadal phases of salinity anomaly are centered at 1996-97 and 2006-07, and negative decadal phases are centered at 2001-02 and 2012-14 (Fig. 6). Observed decadal salinity anomalies on an isopycnal surface exceed 0.2 psu (Fig. 6b). Upper isopycnal surfaces $\left(\sigma_{\theta}=23,24\right.$, and $\left.25 \mathrm{~kg} \mathrm{~m}^{-3}\right)$ show stronger decadal variations than the deeper isopycnal surface $\sigma_{\theta}=26 \mathrm{~kg} \mathrm{~m}^{-3}$. Decadal salinity anomalies appear to be generated in the boundary region at roughly $100^{\circ}-120^{\circ} \mathrm{E}$ and spread westward to the western boundary region between $40^{\circ}$ and $60^{\circ} \mathrm{E}$ (Fig. 6). Transmission speeds are faster in the upper isopycnal surfaces. For example, the propagating speed on $24 \sigma_{\theta}$ is about $9 \mathrm{~cm} \mathrm{~s}^{-1}$ (Argo) and $11 \mathrm{~cm} \mathrm{~s}^{-1}$ (ECCO) (i.e., 38 and 31 months, respectively, from $120^{\circ}$ to $40^{\circ} \mathrm{E}$; Fig. $6 \mathrm{~b}$ ), but only about $5 \mathrm{~cm} \mathrm{~s}^{-1}$ (Argo and ECCO) on $26 \sigma_{\theta}$ (i.e., 65-72 months from $120^{\circ}$ to $40^{\circ} \mathrm{E}$; Fig. $6 \mathrm{~d}$ ).

Figures $7 \mathrm{a}$ and $7 \mathrm{~d}$ present salinity anomalies at $\sigma_{\theta}=$ $25 \mathrm{~kg} \mathrm{~m}^{-3}$ at two locations- $-15^{\circ} \mathrm{S}, 60^{\circ} \mathrm{E}\left(S_{60^{\circ} \mathrm{E}}^{\prime}\right)$ and $15^{\circ} \mathrm{S}$, $90^{\circ} \mathrm{E}\left(S_{90^{\circ} \mathrm{E}}^{\prime}\right)$-in the ECCO and Argo datasets, and Figs. 7b and 7e show the lead-lag correlation coefficients between $S_{60^{\circ} \mathrm{E}}^{\prime}$ and $S_{90^{\circ} \mathrm{E}}^{\prime}$. Power spectra of the ECCO salinity anomaly averaged between $80^{\circ}$ and $90^{\circ} \mathrm{E}$ along $15^{\circ} \mathrm{S}$ (Fig. 7c) suggest that the dominant periods are about 4.5 and 11 years, which represent interannual and decadal time scales, respectively. Clear phase lags can be found between $S_{60^{\circ} \mathrm{E}}^{\prime}$ and $S_{90^{\circ} \mathrm{E}}^{\prime}$. Lead-lag correlation estimation suggests that $S_{90^{\circ} \mathrm{E}}^{\prime}$ leads $S_{60^{\circ} \mathrm{E}}^{\prime}$ by 14 months with a correlation coefficient of 0.71 in the Argo data, and by 22 months with a correlation coefficient of 0.81 in the ECCO (statistically significant at $95 \%$ confidence level). The distance between the two points is $3220 \mathrm{~km}$, and hence the westward transmission speed along $\sigma_{\theta}=$ $25 \mathrm{~kg} \mathrm{~m}^{-3}$ is $\sim 9 \mathrm{~cm} \mathrm{~s}^{-1}$ estimated from the Argo data and $\sim 6 \mathrm{~cm} \mathrm{~s}^{-1}$ from the ECCO; both speeds are roughly consistent with those estimated from the Hovmöller diagram (Fig. 6).

The westward propagation of decadal salinity anomalies along the isopycnals in the Indian Ocean is attributed to the zonal advection by the South Equatorial Current (SEC). The meridional section of mean zonal velocity (1992-2015) across $80^{\circ} \mathrm{E}$ from the ECCO shows that the westward flowing SEC dominates the tropical southern Indian Ocean from about $8^{\circ} \mathrm{S}$ to about $21^{\circ} \mathrm{S}$ and expands southward to $\sim 27^{\circ} \mathrm{S}$ in the deep layer below $26.5 \mathrm{~kg} \mathrm{~m}^{-3}$ (Fig. 8a). The mean zonal geostrophic current of the absolute geostrophic velocities from Argo (AGVA; Gray and Riser 2014) is shown for comparison (Fig. 8b, averaged over 2004-10). The AGVA use velocity at 900 dbar estimated from the trajectory data provided by the Argo floats (Gray and Riser 2014). The average speed of the SEC is maximum at $19 \mathrm{~cm} \mathrm{~s}^{-1}$ in the upper $50 \mathrm{~m}$ between $9^{\circ}-15^{\circ} \mathrm{S}$. On isopycnal surfaces $\sigma_{\theta}=$ $23,24,25$, and $26 \mathrm{~kg} \mathrm{~m}^{-3}$, the SEC speeds are about $8,9,8$, and $5 \mathrm{~cm} \mathrm{~s}^{-1}$, respectively. Hence the estimated westward transmission speed of the salinity signals, $5-9 \mathrm{~cm} \mathrm{~s}^{-1}$ (Fig. 7), also matches the ocean current velocity very well. Interannual to decadal salinity anomalies that are generated in the southeastern Indian Ocean are advected through the Indian Ocean basin to the western Indian Ocean in about 3 years assuming a distance of $7513 \mathrm{~km}$ from $120^{\circ}$ to $50^{\circ} \mathrm{E}$ along $15^{\circ} \mathrm{S}$ at a speed of $8 \mathrm{~cm} \mathrm{~s}^{-1}$.

\section{c. Salinity composite and budget analyses}

To better understand the dynamics of the interannual to decadal variability of the Indian Ocean salinity, we performed composite and salinity budget analyses in the southeastern Indian Ocean.

\section{1) COMposite AnAlysis}

Observed sea surface freshwater flux $(E-P)$, wind stress, and SLA are composited over the freshening period June 2007-June 2013 and over the salinification periods in January 2004-June 2007 and June 2013-April 2017 (freshening and salinification periods are defined by Figs. 3 and 4).

During the freshening period, a slight increase of freshwater input (negative $E-P$ anomaly) at the sea surface can be seen in the southeastern Indian Ocean, 
a. $\sigma_{\theta}=23 \mathrm{~kg} \mathrm{~m}^{-3}$
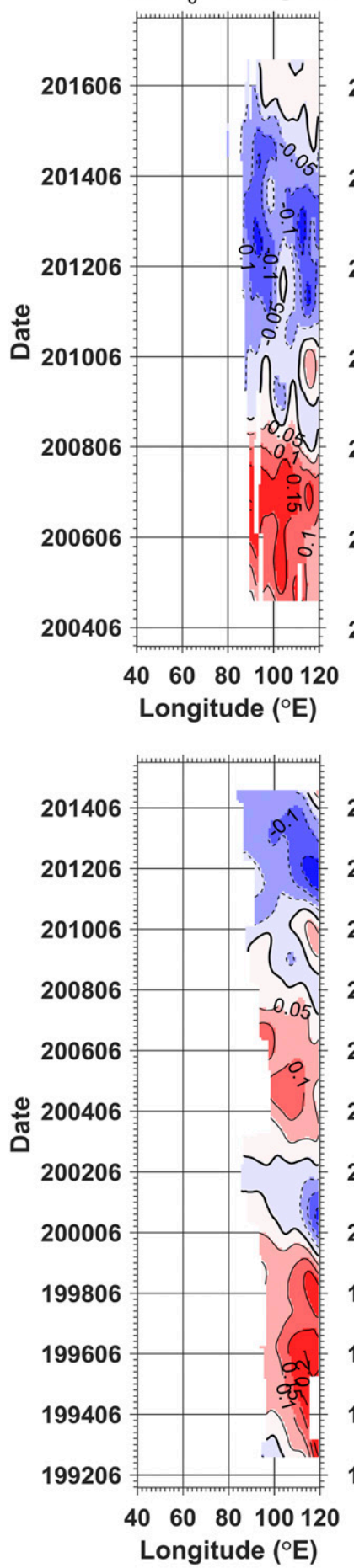

b. $\sigma_{\theta}=24 \mathrm{~kg} \mathrm{~m}^{-3}$
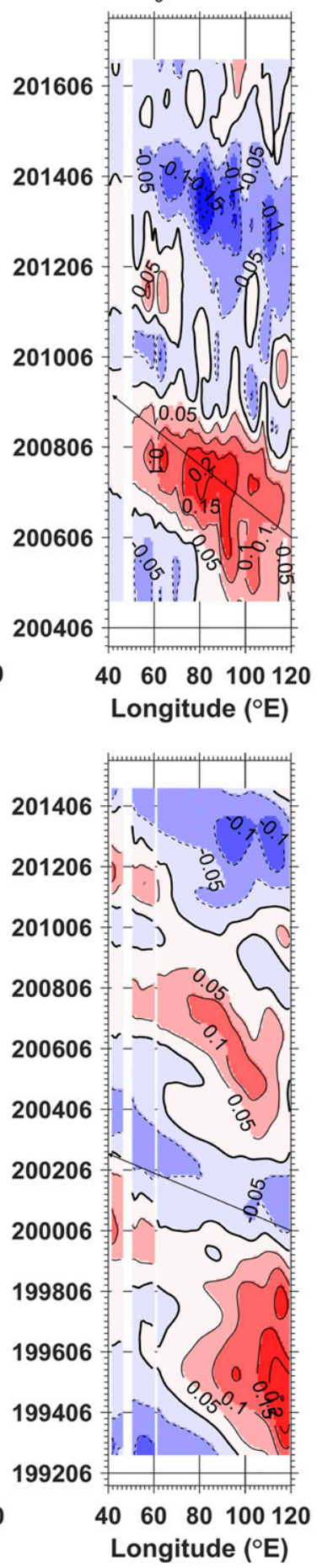

C. $\sigma_{\theta}=25 \mathrm{~kg} \mathrm{~m}^{-3}$
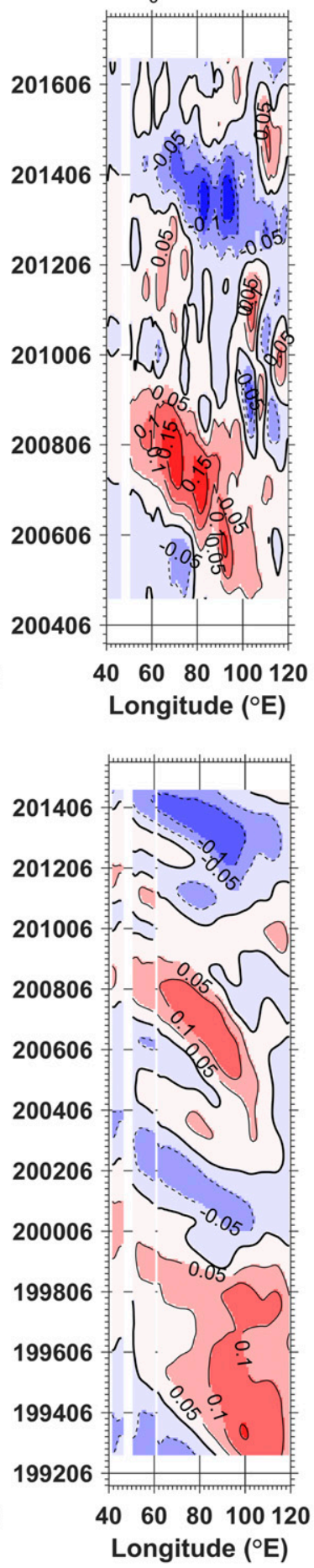

d. $\sigma_{\theta}=26 \mathrm{~kg} \mathrm{~m}^{-3}$
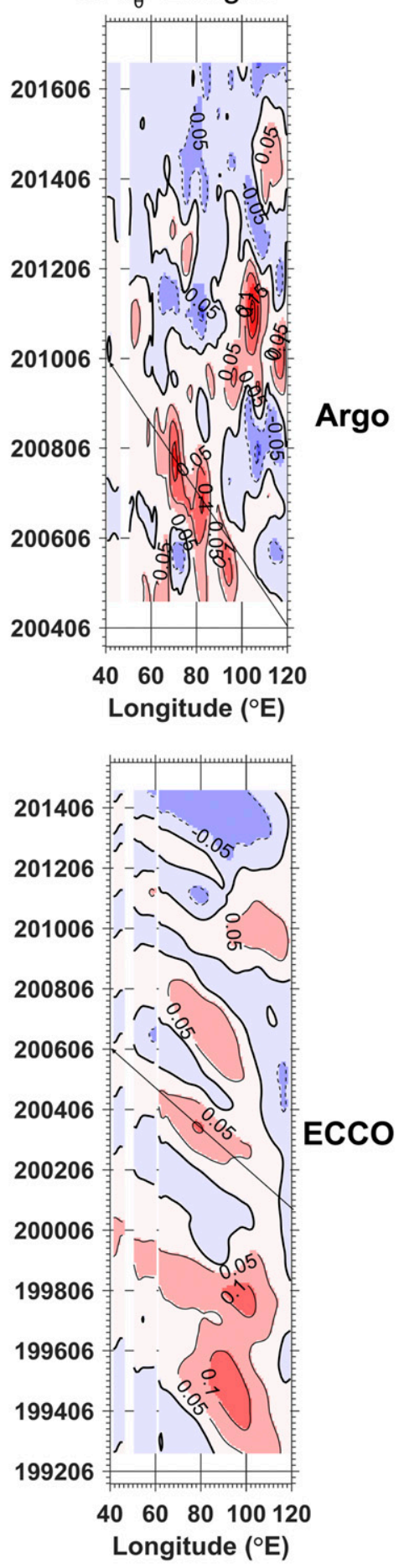

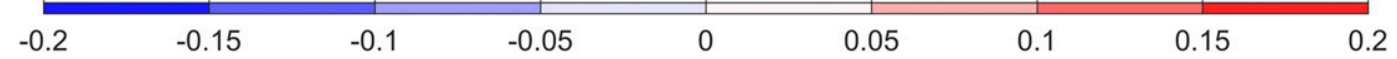

FIG. 6. Hovmöller diagrams of (top) Argo and (bottom) ECCO salinity anomalies (color and contour lines; psu) along $15^{\circ} \mathrm{S}$ at various isopycnal surfaces: $\sigma_{\theta}=$ (a) 23 , (b) 24, (c) 25 , and (d) $26 \mathrm{~kg} \mathrm{~m}^{-3}$. High-frequency signals are excluded by applying a 13-month running mean twice. Black lines in (b) and (d) denote the examples of signal pathways used to estimate the propagation speed. 
a.

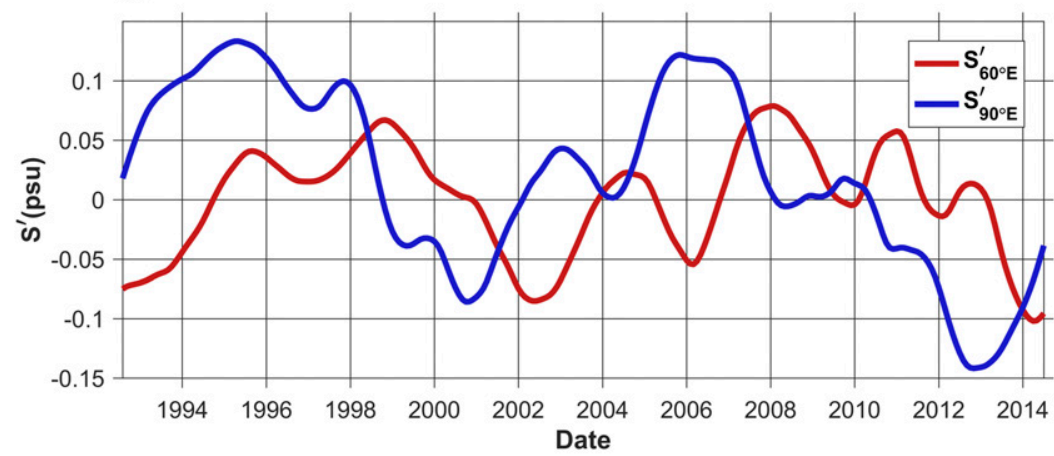

c.

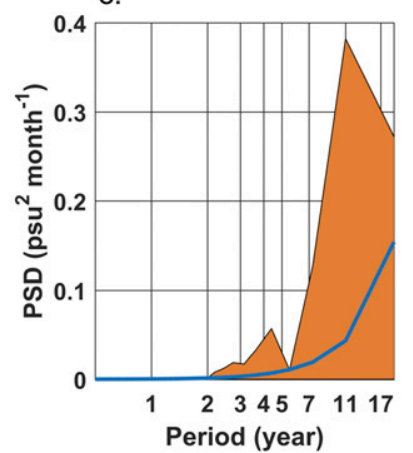

d.

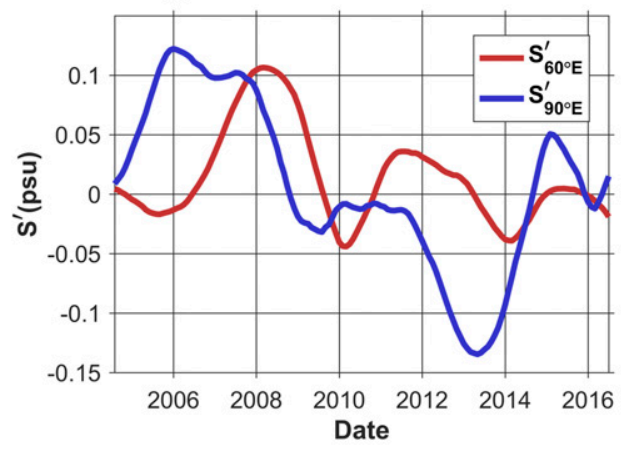

b.

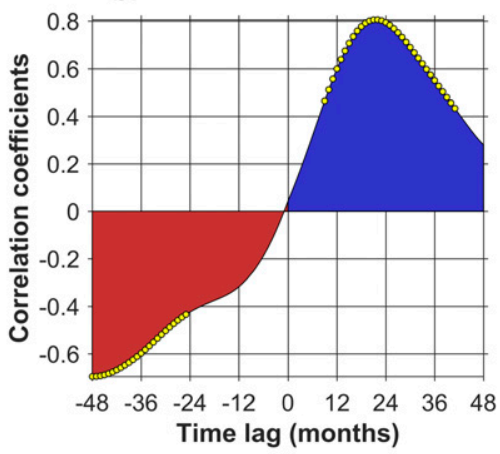

e.

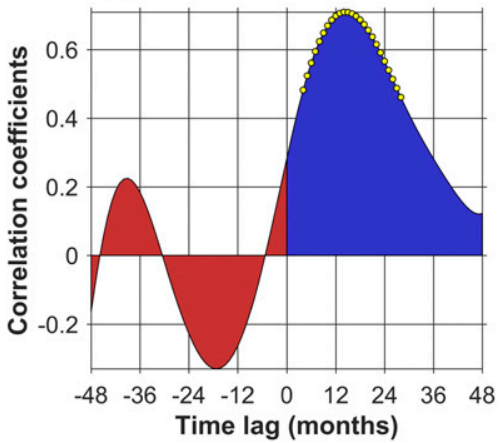

FIG. 7. (a),(d) Isopycnal salinity anomalies $\left(\sigma_{\theta}=25 \mathrm{~kg} \mathrm{~m}^{-3}\right)$ at $15^{\circ} \mathrm{S}, 60^{\circ} \mathrm{E}\left(S_{60^{\circ} \mathrm{E}}^{\prime}\right)$ and $15^{\circ} \mathrm{S}, 90^{\circ} \mathrm{E}\left(S_{90^{\circ} \mathrm{E}}^{\prime}\right)$ and (b),(e) lead-lag correlation coefficients between $S_{90^{\circ} \mathrm{E}}^{\prime}$ and $S_{60^{\circ} \mathrm{E}}^{\prime}$ from (top) ECCO and (bottom) RG Argo. (c) The power spectrum (shading area) of ECCO salinity anomaly averaged over $80^{\circ}-90^{\circ} \mathrm{E}$ along $15^{\circ} \mathrm{S}$ (blue line indicates $95 \%$ confidence level). Positive lags (blue) in (b) and (e) indicate lead by $S_{90^{\circ} \mathrm{E}}^{\prime}$. Yellow dots denote the $95 \%$ confidence level determined using an effective degree of freedom.

but its amplitude is less than $-0.5 \mathrm{~mm}^{-1}{ }^{-1}$ and close to zero in most regions. In contrast, the Indonesian seas, an upstream region for the Indian Ocean SEC and ITF, shows a significant increase of sea surface freshwater input with an anomaly from -1.0 to $-1.5 \mathrm{~mm}$ day $^{-1}$ (Fig. 9). During the freshening period, the western Pacific Ocean experiences enhanced trade winds and increased SLA and oceanic convergence, but the southeastern Indian Ocean experiences a clockwise wind anomaly with oceanic divergence and slightly weaker SLA change relative to western Pacific Ocean. The spatial pattern of SLA and wind stress indicates an increase in pressure gradient from the Pacific Ocean to the Indian Ocean and so points to an intensifying ITF during the freshening periods (e.g., Wyrtki 1987; Potemra et al. 1997; Hu and Sprintall 2017a).

Composited sea surface freshwater flux and upperlayer ocean circulation are further investigated using ECCO outputs. The sea surface freshwater input anomaly during the freshening period is close to zero relative to the salinification periods in the southeastern Indian Ocean, but upstream in the Indonesian seas the freshwater input is significantly increased with an $E-P$ anomaly from -1.0 to $-1.5 \mathrm{~mm} \mathrm{day}^{-1}$ (Fig. 10), which is in agreement with observations (Fig. 9a). The upperlayer mean $(0-400 \mathrm{~m})$ oceanic circulation during the freshening period shows significant enhancement of the Pacific SEC and the southern component of the Pacific NEC that together lead to a strengthening of the ITF (Fig. 10b). Hu and Sprintall (2016) showed the upperlayer salinity anomalies on interannual time scales along the ITF routes from the western Pacific to the eastern Indian Oceans (their Fig. 10) and found that the ITF clearly transfers salinity signals generated in the Indonesian seas into the Indian Ocean. This supports the Phillips et al. (2005) study that suggested that increased freshwater input in the Maritime Continent and the enhanced ITF would lead to an enhancement of freshwater transport into the Indian Ocean.

\section{2) SALinity BUdGeT}

We perform a salinity budget [Eq. (1)] to quantitatively examine the physical processes that determine the interannual to decadal variability of oceanic salinity in the southeastern Indian Ocean. A control volume, defined by the horizontal boundaries of $80^{\circ}-115^{\circ} \mathrm{E}, 5^{\circ}-32^{\circ} \mathrm{S}$, and 


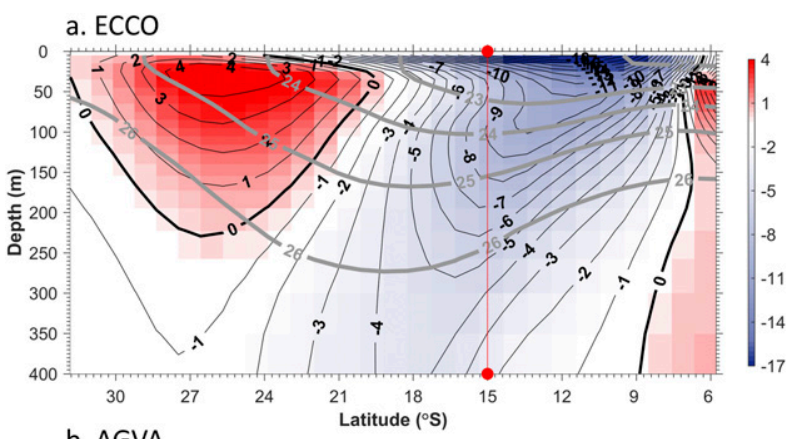

b. AGVA

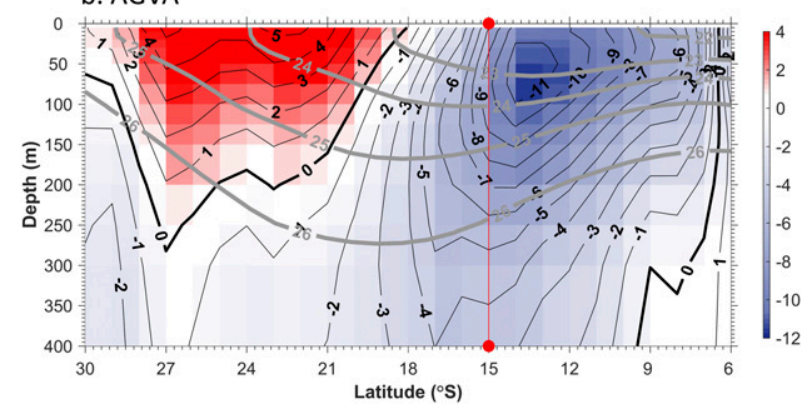

FIG. 8. Mean zonal velocity across $80^{\circ} \mathrm{E}$ (color and black contour lines; $\mathrm{cm} \mathrm{s}^{-1}$ ) from (a) ECCO and (b) AGVA. Isopycnal surfaces $\sigma_{\theta}$ (gray contour lines; $\mathrm{kg} \mathrm{m}^{-3}$ ) superimposed on zonal velocity are from RG Argo climatology averaged over 2004-17. The red line marks the profile at $15^{\circ} \mathrm{S}$.

from the sea surface to 400-m depth, is selected for the salinity budget analysis. Salinity, current velocities, evaporation, and precipitation for the salinity budget calculations are extracted from the ECCO v4.3 output.

The sum of monthly integrated surface forcing and advection terms $\left(\int F_{s} d t+\int \operatorname{Adv} d t\right)$ matches the salinity variation term $[S]^{\prime}$ very well. The advection dominates the salinity variability whereas the surface forcing, dominated by the local sea surface freshwater flux, plays a secondary role (Fig. 11). However, it is possible that the variations of the advection and local sea surface freshwater flux are interrelated as they both might respond to climate modes through oceanic and atmospheric teleconnections (e.g., Nagura and Kouketsu 2018). The correlation coefficient is 0.83 between the salinity anomalies and the time-integrated advection anomalies and 0.57 between the salinity anomalies and the time-integrated surface forcing anomalies.

During the freshening period in ECCO (July 1998December 2001 and July 2007-June 2013), advection of freshwater, especially zonal advection, dominates the sign and amplitude of salinity variability. During salinification periods (January 1992-June 1998 and January 2002-June 2007), advection of freshwater leads to a significant positive salinity anomaly. Further calculation shows that the advection of mean salinity by anomalous
ITF/SEC velocity dominates the total variability of salinity advection in the ITF outflow region, suggesting that the variability of ITF/SEC transport is essential (figure not shown). The surface flux term plays an important role in the salinification period January 2002June 2007. Advection through the bottom boundary is very weak during all time periods (Fig. 12).

\section{Relationship to climate modes and predictability}

Interannual to decadal variability of the Indian Ocean salinity is mainly forced through horizontal advection of freshwater, most likely upstream from the Indonesian seas via the ITF, with additional contributions from local freshwater forcing.

Previous studies have shown that interannual to decadal variability of the ITF and freshwater transport between the Indian and Pacific Ocean basins are linked to the major climate modes including ENSO, the IOD, and the PDO (e.g., Hu and Sprintall 2016, 2017a). Here we link the interannual to decadal variability of oceanic salinity in the southeastern Indian Ocean to the ENSO, IOD, and PDO indices.

Figures 13a-d compare the PDO, Niño-3.4 indices, and DMI with the upper 400-m layer salinity anomaly averaged within the tropical southeastern Indian Ocean (here defined as $100^{\circ}-120^{\circ} \mathrm{E}$ and $12^{\circ}-16^{\circ} \mathrm{S}$ ). Lead-lag correlation coefficients between the southeastern Indian Ocean salinity anomaly and the climate indices are shown in the right panels of Figs. 13f-h. Results suggest that the PDO index leads the southeastern Indian Ocean salinity anomaly by 10 months with a significant correlation coefficient of 0.82 . The Niño-3.4 index leads the southeastern Indian Ocean salinity anomaly by 7 months and also shows a significant correlation coefficient of 0.63 . But the southeastern Indian Ocean salinity anomaly shows no significant simultaneous or lagged correlation with the DMI. Hu and Sprintall (2016) suggested that the Niño-3.4 index leads the ITF outflow by 7-8 months due to advection within the Indonesian seas.

The significant lagged correlation between the southeastern Indian Ocean salinity anomaly and the PDO index makes it possible to assess its predictability. Here we propose a statistical prediction model based on a regression analysis:

$$
S_{\mathrm{SEIO}}^{\prime}(\tau)=\gamma_{0}+\gamma_{1} \operatorname{PDO}(\tau-10)
$$

where $S_{\text {SEIO }}^{\prime}(\tau)$ is the mean salinity anomaly in the southeastern Indian Ocean at month $\tau$, and $\gamma_{0}$ and $\gamma_{1}$ are coefficient estimates for a multilinear regression of the response in the southeastern Indian Ocean salinity anomaly based on the predictor $\operatorname{PDO}(\tau-10)$, which is 

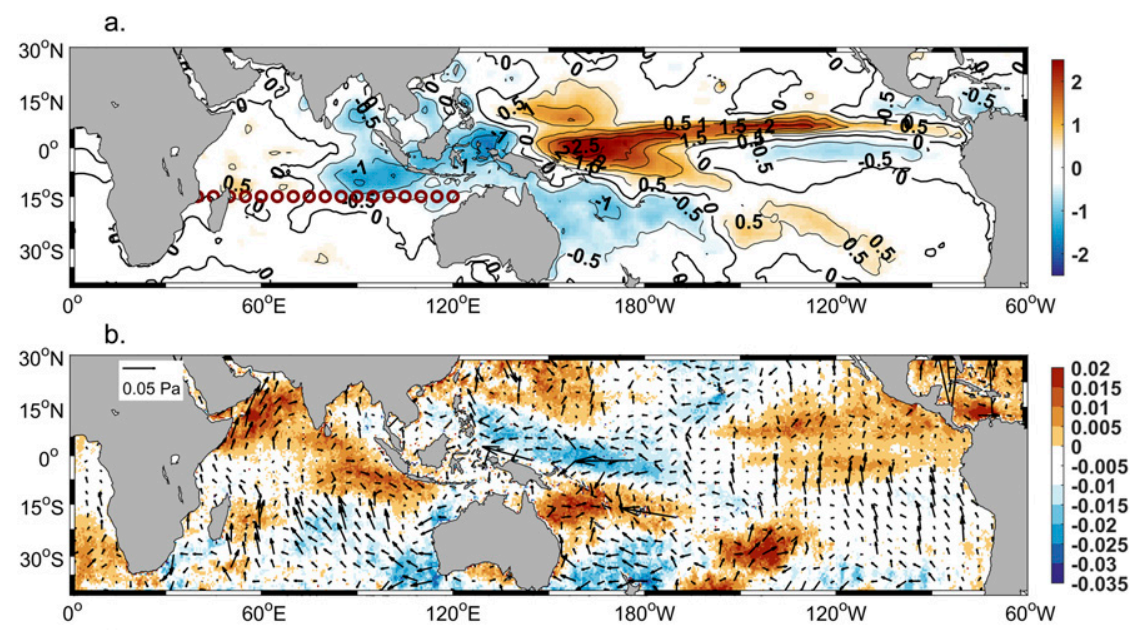

C.

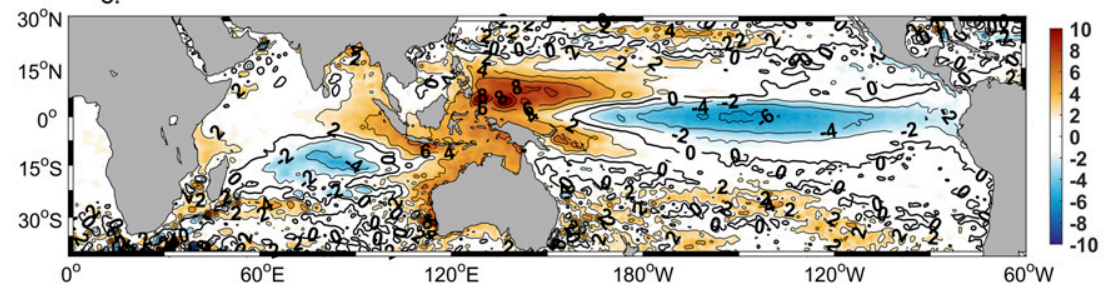

FIG. 9. Differences (composite over freshening periods minus that over salinification periods) of (a) $E-P\left(\mathrm{~mm} \mathrm{day}^{-1}\right)$, (b) wind stress (vectors; $\mathrm{Pa}$ ) and zonal wind stress (color; $\mathrm{Pa}$ ), and (c) SLA $(\mathrm{cm})$. Freshening periods are defined as $\partial S^{\prime} / \partial t<0$ while salinification periods are defined as $\partial S^{\prime} / \partial t>0$, where $S^{\prime}$ is the vertical mean salinity anomaly in the southeastern Indian Ocean shown in Fig. 4a.

the PDO index at month $\tau-10$ months. Here we find $\gamma_{0}=0.0163$ and $\gamma_{1}=0.0303$. Figure $13 \mathrm{e}$ presents the time series of salinity anomaly predicted by the regression model and comparison between the regression model result and the salinity anomaly averaged in the southeastern Indian Ocean from ECCO. Lead-lag correlation coefficients are shown in Fig. 13i. The model prediction salinity anomaly matches the ECCO salinity
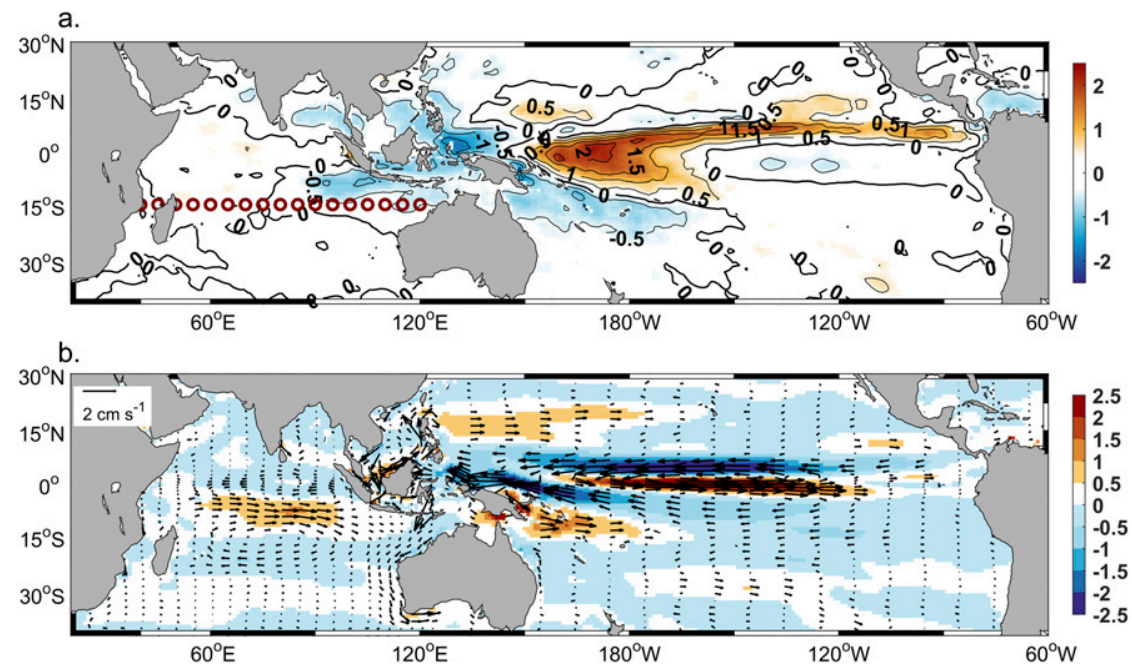

FIG. 10. Differences (composite over freshening periods minus that over salinification periods) of (a) sea surface freshwater flux (positive for ocean's freshwater loss) (mm day ${ }^{-1}$ ) and (b) upper-layer oceanic current (vector) and zonal current (color; $\mathrm{cm} \mathrm{s}^{-1}$ ) averaged over 0-400 $\mathrm{m}$ from ECCO. Freshening and salinification periods are defined as described in Fig. 9. 

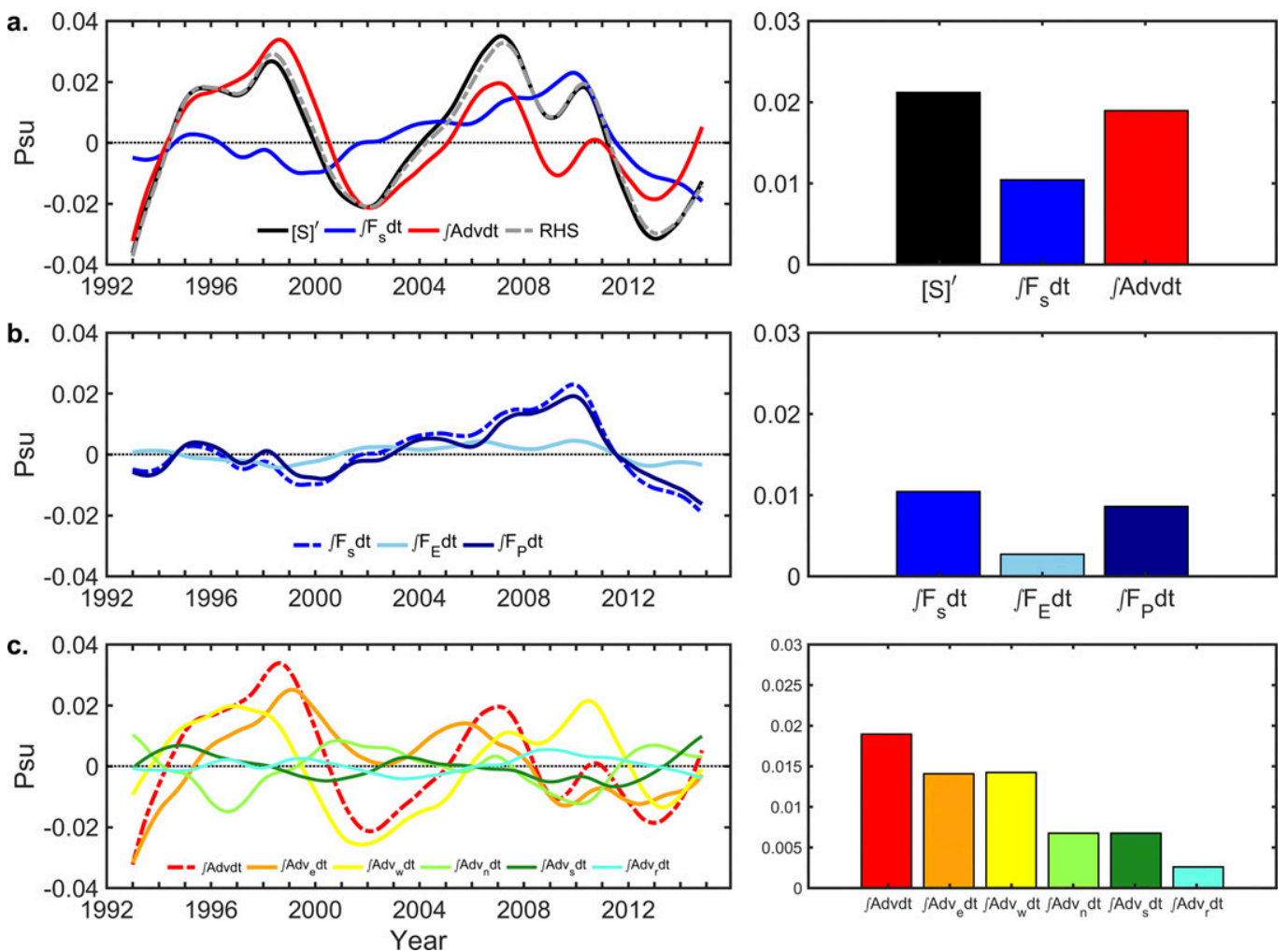

FIG. 11. (a) Anomalous salinity averaged over upper 400-dbar area of the southeastern Indian Ocean (black; $[S]^{\prime}$ ) and time-integration (integrations are performed over an integration interval of one month) salinity budget terms: surface forcing (blue; $\int F_{s} d t$ ) and advections (red; $\int \operatorname{Adv} d t$ ). RHS indicates the sum of $\int F_{s} d t$ and $\int \operatorname{Adv} d t$. The right panel shows standard deviations of $[S]^{\prime}$, time-integration surface forcing, and advection. The salinity budget terms are also shown for (b) evaporation $\left[F_{E}=\left(\iint_{A} E d A / V\right)\right]$ and precipitation $\left[F_{P}=\left(-\iint_{A} P d A / V\right)\right]$ and (c) advection through the box sides. Linear trends and high-frequency variations are removed. Positive values in the left-hand panels indicate increased salinity in the box.

anomaly quite well with a simultaneous and significant correlation coefficient of 0.82 , which implies that the model successfully predicts about $67 \%$ of the interannual to decadal variation of salinity variability in the southeastern Indian Ocean.

Nagura and Kouketsu (2018) suggested that the salinity anomalies on the $24-26 \sigma_{\theta}$ isopycnal surfaces in the southern Indian Ocean during 2004-15 were subducted and advected from outcropping regions in the southeastern Indian Ocean and hence associated with Ningaloo Niño and ENSO. However, they also emphasized the influence of the Indonesian seas. Hence, on an interannual time scale, both the ENSO and Ningaloo Niño are likely important in causing the salinity variability via the ITF into the upper layer of the southern Indian Ocean.

\section{Discussion on uncertainty}

The RG Argo gridded dataset is produced on the basis of Argo profiles since 2004. However, the number and spatial homogeneity of Argo profiles have always been insufficient to produce a high-resolution gridded map (e.g., $<1^{\circ}$ horizontally) of oceanic temperature and salinity, especially during the early years of the Argo era. Figure 14 shows number of Argo profiles (adjusted and delayed mode; Wong et al. 2019) in the domain enclosed by $60^{\circ}-110^{\circ} \mathrm{E}$ and $40^{\circ} \mathrm{S}-15^{\circ} \mathrm{N}$ and distribution of salinity profiles in 2004 and 2010. Obviously, the number of Argo profiles in a month and within a $1^{\circ} \times 1^{\circ}$ is nearly always below 0.5 , indicating that the Argo profiles might be insufficient to resolve monthly variations with a spatial resolution of $1^{\circ}$ (Fig. 14a). However, the number of Argo profiles over any year-long period within any $1^{\circ} \times 1^{\circ}$ grid cell is much better, typically between two and five profiles, implying that the Argo data are able to capture the general features of interannual and lowerfrequency variability in salinity (Fig. 14b). In the three boxes that are our focus, the number of salinity profiles is greater than average compared to other regions of the Indian Ocean (Fig. 14c). The Argo profiles in the Indian 

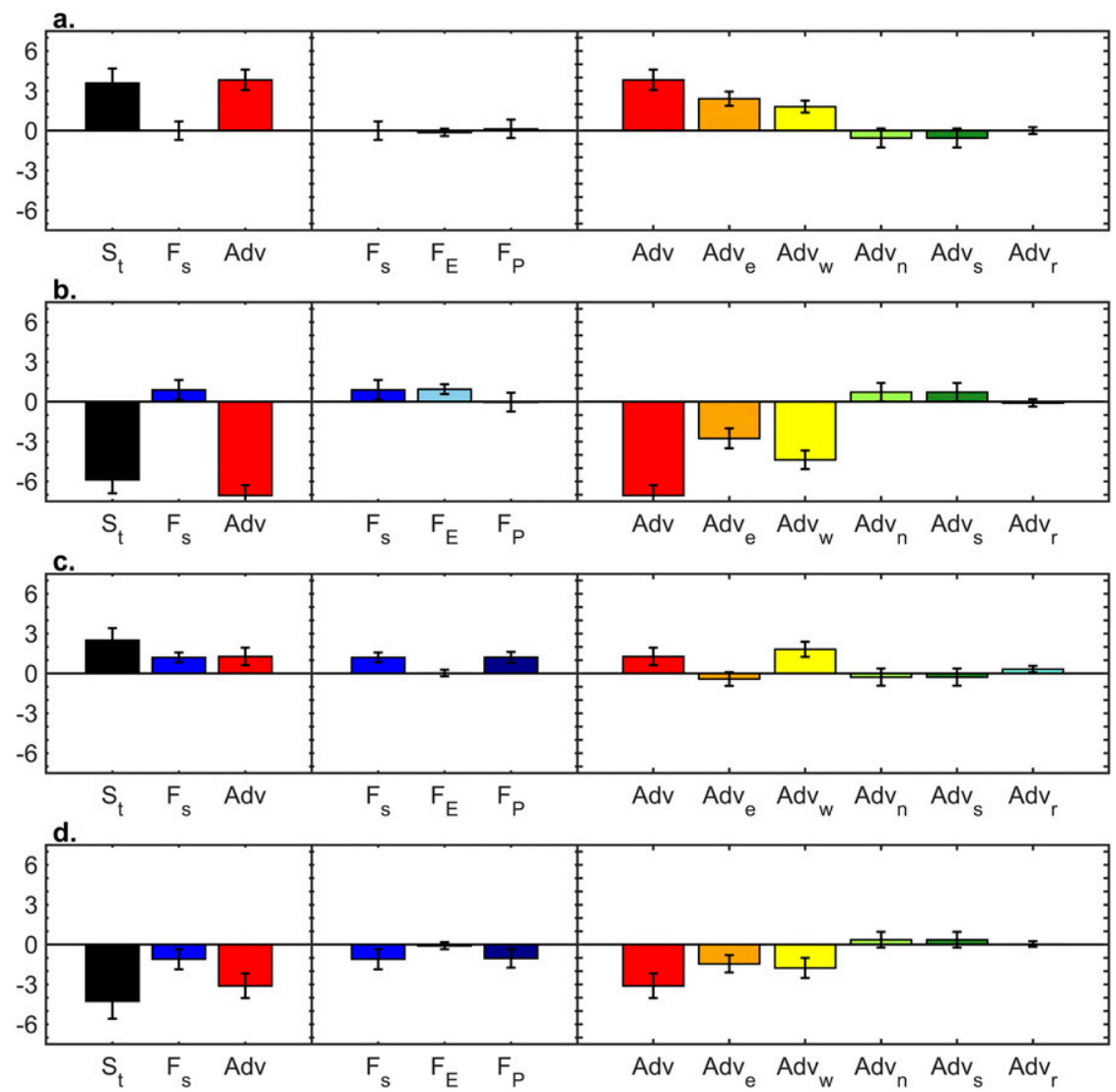

FIG. 12. Salinity budget terms and subitems $\left(10^{-10} \mathrm{psu} \mathrm{s}^{-1}\right)$ averaged over various periods: (a) January 1992-June 1998, (b) July 1998-December 2001, (c) January 2002-June 2007, and (d) July 2007-June 2013 defined according to the sign of salinity change shown in Fig. 11a. The error bars in (a)-(c) represent one standard error based on a Student's $t$ test.

Ocean are not uniformly dispersed horizontally, especially in the marginal seas (Fig. 14d), but their homogeneous distribution has improved in recent years (Fig. 14e).

Errors or uncertainties in the Argo profile data may be induced by instrument errors, uncertainty from conductivity cell thermal mass adjustment, and so on. Errors or uncertainties in the adjusted Argo profile data have been estimated according to standard quality control (QC) procedures (Wong et al. 2019). Here we examine the status of errors or uncertainties in adjusted salinity profiles (about 0.4 million profiles) provided by Wong et al. (2019). Figure 15 presents the monthly salinity errors averaged over the upper 400-dbar layer and the percentage frequency of errors of all the available salinity profiles during 2004-18. It is clear that about $90 \%$ of the salinity profiles have an error of about $0.01 \mathrm{psu}$. The monthly mean error in salinity profiles has decreased since about 2010.

As we mentioned, the interannual to decadal variability of the southern Indian Ocean salinity averaged over the upper 400-m layer has an amplitude of 0.02 $0.04 \mathrm{psu}$, which is $1-3$ times greater than the errors or uncertainty, indicating that the observed interannual to decadal variability of the Indian Ocean salinity is significant. The ECCO assimilates observations including Argo salinity and sea surface freshwater flux within the numerical model. The uncertainty of the ECCO salinity therefore comes from both the inputdependent errors from Argo and the surface freshwater flux as well as model-dependent errors (e.g., Ponte and Vinogradova 2016). Further studies are needed to quantify the exact uncertainty in the ECCO salinity.

\section{Conclusions}

In this study, we used the 14-yr Argo observational dataset and the state-of-the-art data-assimilating numerical model ECCO, along with observations of airsea fluxes, to investigate the mechanisms of interannual to decadal salinity variability in the Indian Ocean. 


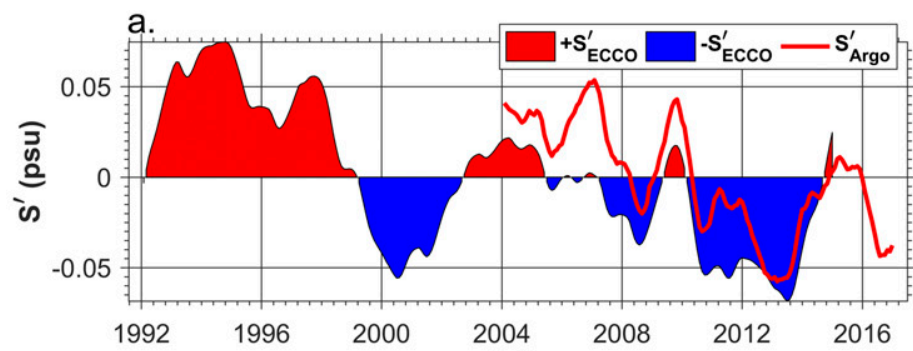

b.
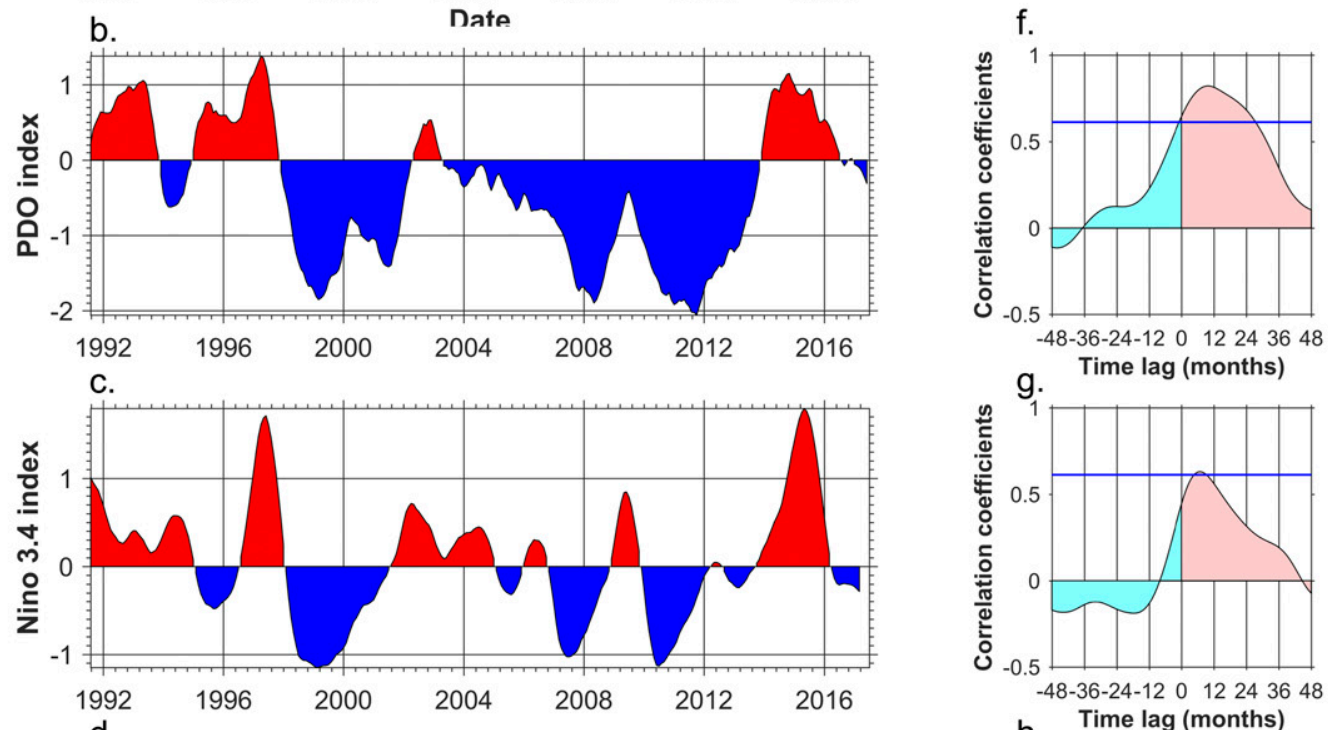

d.
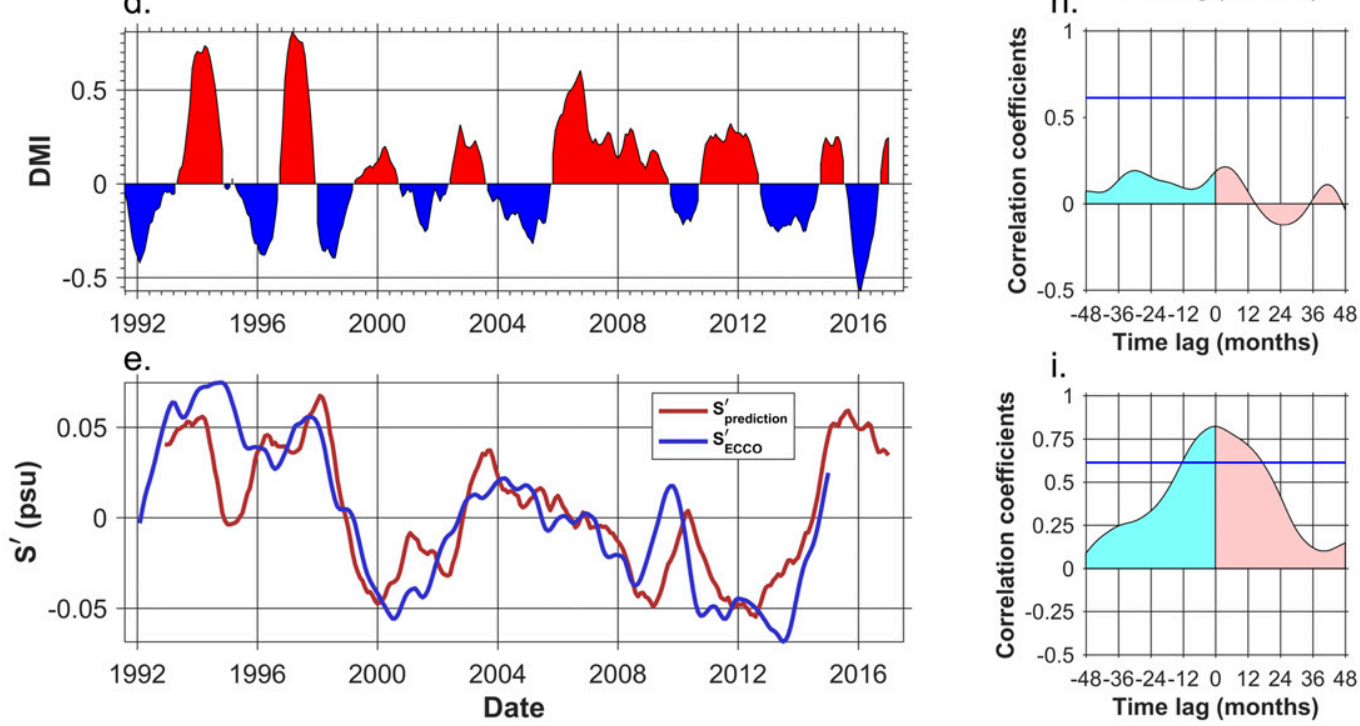

FIG. 13. Time series of (a) 0-400-m-layer salinity anomaly averaged over the region $100^{\circ}-120^{\circ} \mathrm{E}, 12^{\circ}-16^{\circ} \mathrm{S}$ from ECCO and Argo; (b) the PDO index; (c) the Niño-3.4 index; (d) the DMI; and (e) the salinity anomaly from ECCO (blue) and the predicted salinity anomaly from the PDO index (red) lagged by 10 months. All the time series are filtered by a 13-month running mean. (f)-(i) Lag-lead correlation between the corresponding index in the left panel and ECCO salinity anomaly in (a). The 98\% confidence level estimated using a Student's $t$ test with an effective degree of freedom of 12 is indicated in blue. 

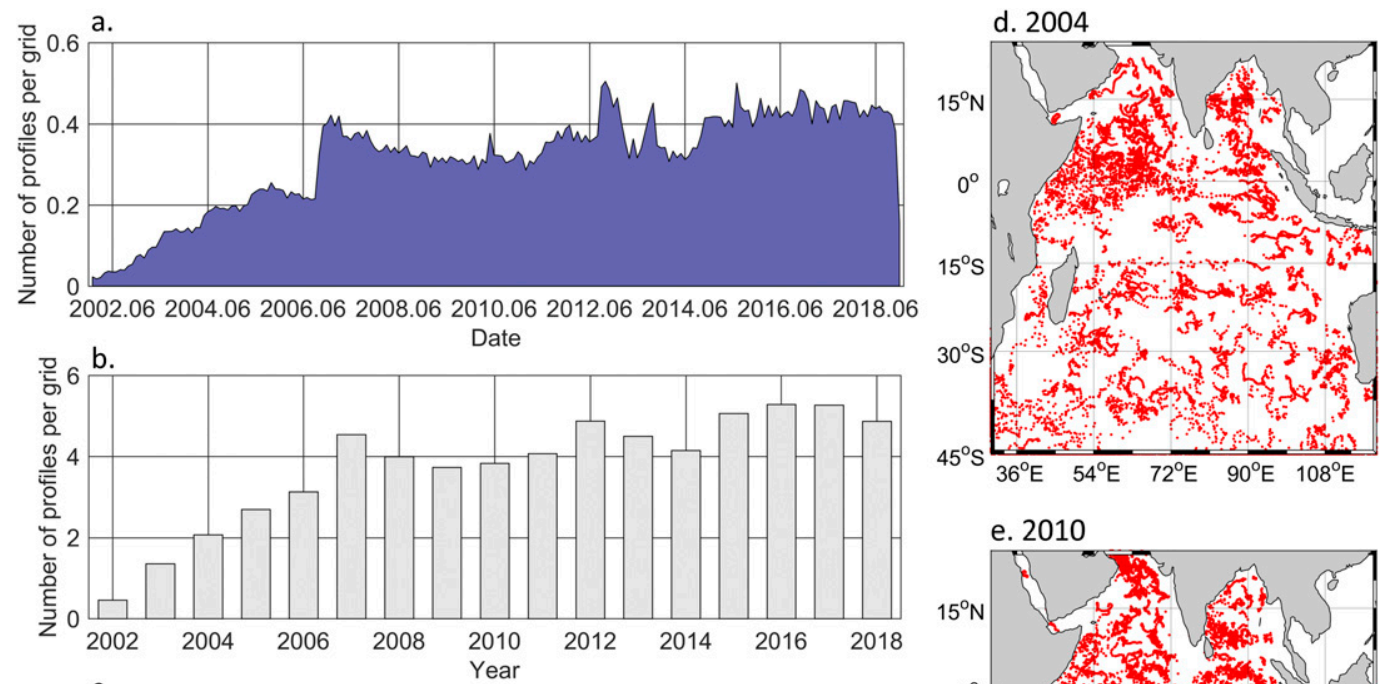

C.
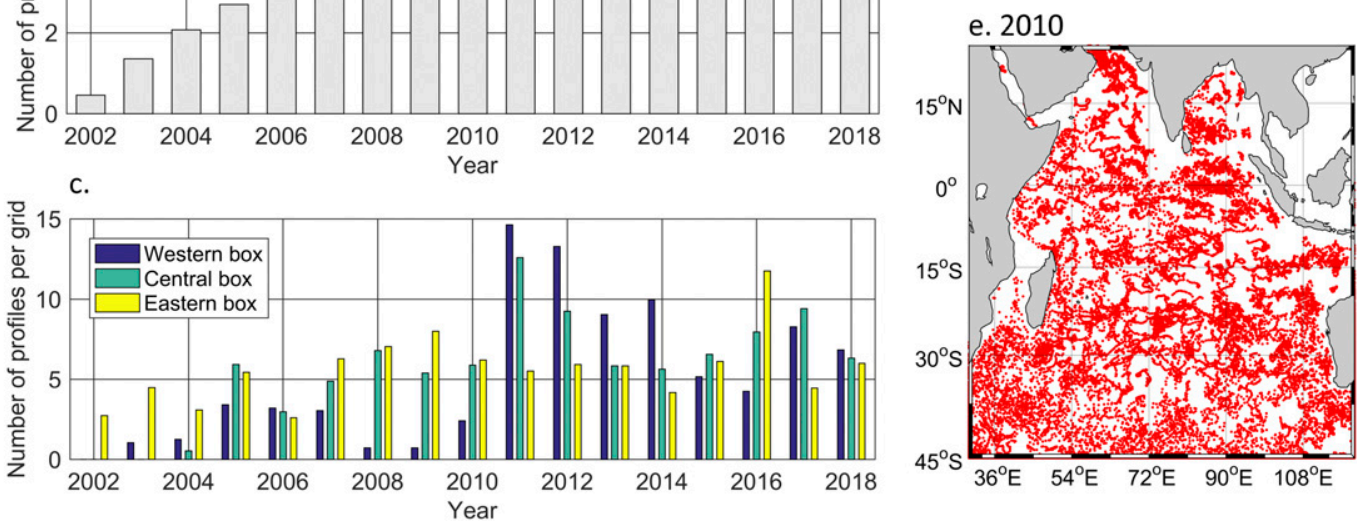

FIG. 14. (left) Number of Argo profiles in the Indian Ocean. (a) Monthly number of Argo profiles in the domain $60^{\circ}-110^{\circ} \mathrm{E}$ and $40^{\circ} \mathrm{S}-15^{\circ} \mathrm{N}$ (per $1^{\circ} \times 1^{\circ}$ grid). (b) Yearly number of Argo profiles in the domain $60^{\circ}-110^{\circ} \mathrm{E}$ and $40^{\circ} \mathrm{S}-15^{\circ} \mathrm{N}$ (per $1^{\circ} \times 1^{\circ}$ grid). (c) Yearly number of Argo profiles as in (b) but for the three boxes shown in Fig. 2. (right) Distribution of Argo profiles in (d) 2004 and (e) 2010.

The southeastern Indian Ocean shows the strongest interannual to decadal variability. Two freshening periods and two salinification periods have been identified. Westward advection of salinity anomalies along isopycnal surfaces was detected in the southern Indian Ocean and attributed to zonal advection anomalies due to the Indian Ocean SEC.

Composite analysis and a salinity budget were performed to examine the role of ocean dynamics and the a.

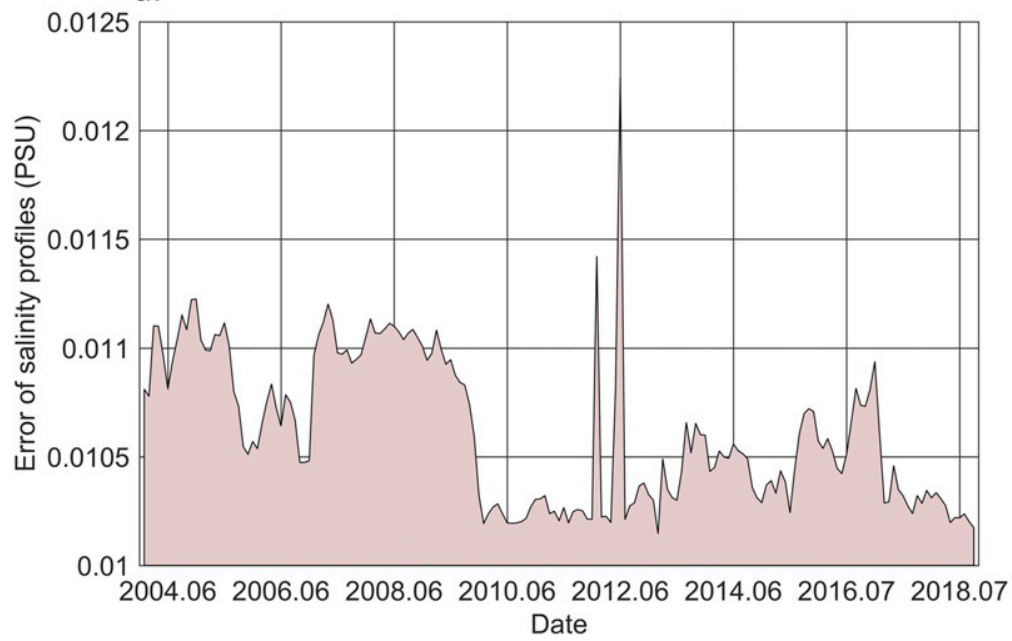

b.

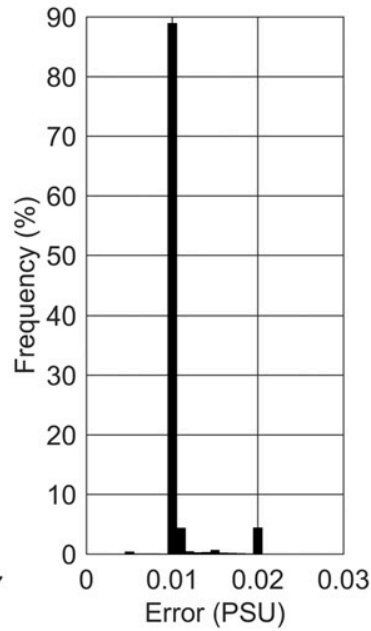

FIG. 15. (a) Vertical and monthly mean error of salinity profiles in the domain $60^{\circ}-110^{\circ} \mathrm{E}$ and $40^{\circ} \mathrm{S}-15^{\circ} \mathrm{N}$.

(b) Frequency of salinity error shown in (a) (percentage relative to the total number of salinity profiles). 
sea surface freshwater flux input. Interannual to decadal fluctuations of horizontal advection of freshwater associated with the ITF/SEC are the driving forcing of ocean salinity variability in the southeastern Indian Ocean and explain $68 \%$ of the salinity variance. Surface flux variation plays a secondary but important role as well, contributing about $32 \%$ of the interannual to decadal fluctuation of salinity in the southeastern Indian Ocean.

The dominant climate modes driving the interannual to decadal salinity variability of the southeast Indian Ocean are the PDO and ENSO cycles. The IOD has no significant correlation with the interannual to decadal salinity variability of the southeastern Indian Ocean. The PDO and ENSO lead the interannual to decadal salinity variability of the southeastern Indian Ocean by several months. The ITF/SEC provides a conduit for the transfer of PDO- and ENSO-related salinity signals from the Pacific to the Indian Ocean. A statistical model is proposed to predict the salinity variability of the southeast Indian Ocean with the PDO index. Results show that the statistical model successfully predicts about $68 \%$ of salinity variability on interannual to decadal time scales.

Long-term accumulation of in situ observations is still needed to better understand the Indian Ocean salinity variability on interannual to decadal time scales. In situ salinity observations are largely absent in the Indonesian seas, and as a consequence salinity processes within this region are unclear. The Indonesian seas are a place of significant freshwater input to the ITF and the global thermohaline circulation, and a significant portion of the ITF water is thought to be advected eventually into the Atlantic Ocean (e.g., Song et al. 2004), but the importance of the long-term salinity variations in the Indonesian seas and Indian Ocean on the thermohaline circulation is still unclear.

Acknowledgments. RG Argo data are provided by the Scripps Institution of Oceanography at University of California San Diego (http://sio-argo.ucsd.edu/RG_ Climatology.html). AVISO sea level data can be found at http://www.aviso.oceanobs.com/duacs/. The GPCP precipitation can be found at https://www.ncei.noaa.gov/data/ global-precipitation-climatology-project-gpcp-monthly/ access/. The OAFlux product is available at http:// oaflux.whoi.edu/. The PDO index provided by NOAA/ NCEI can be found at https://www.ncdc.noaa.gov/ teleconnections/pdo/. The DMI index and Niño-3.4 index are provided by NOAA/ESRL at https://stateoftheocean. osmc.noaa.gov/sur/ind/dmi.php and https://www.esrl.noaa. gov/psd/data/correlation/nina34.data, respectively. The ECCO assimilations are available at http://ecco.jpl.nasa. gov/. Shijian Hu was supported by the Key Research
Program of Frontier Sciences, CAS (QYZDB-SSWSYS023) and the National Natural Science Foundation of China (Grants 91858101, 41776018, and 41730534). Ying Zhang was supported by the China Scholarship Council. Yan Du was supported by the National Natural Science Foundation of China (Grant 41525019). Janet Sprintall was supported by NOAA's Climate Program Office, Climate Variability and Predictability Program (Award NA17OAR4310257). This is a cooperative work when Shijian Hu visited Ming Feng at CSIRO O\&A Crawley. Ming Feng was supported by the CSHOR, which is a joint initiative between the Qingdao National Laboratory for Marine Science and Technology (QNLM), CSIRO, University of New South Wales and University of Tasmania. This work benefits from the Northwestern Pacific Ocean Circulation and Climate Experiment (NPOCE)/CLIVAR program. We are grateful to the three anonymous reviewers and Editor Rong Zhang for their insightful comments and suggestions.

\section{REFERENCES}

Adler, R. F., and Coauthers, 2003: The version-2 Global Precipitation Climatology Project (GPCP) monthly precipitation analysis (1979-present). J. Hydrometeor., 4, 1147-1167, https://doi.org/ 10.1175/1525-7541(2003)004<1147:TVGPCP > 2.0.CO;2.

Ando, K., and Coauthors, 2017: Fifteen years progress of the TRITON array in the western Pacific and eastern Indian Oceans. J. Oceanogr., 73, 403-426, https://doi.org/10.1007/s10872-0170414-4.

Balaguru, K., G. R. Foltz, L. R. Leung, and K. A. Emanuel, 2016: Global warming-induced upper-ocean freshening and the intensification of super typhoons. Nat. Commun., 7, 13670, https://doi.org/10.1038/ncomms13670.

Da-Allada, C. Y., F. Gaillard, and N. Kolodziejczyk, 2015: Mixedlayer salinity budget in the tropical Indian Ocean: Seasonal cycle based only on observations. Ocean Dyn., 65, 845-857, https://doi.org/10.1007/s10236-015-0837-7.

Dee, D. P., S. M. Uppala, A. J. Simmons, P. Berrisford, P. Poli, S. Kobayashi, and P. Bechtold, 2011: The ERA-Interim reanalysis: Configuration and performance of the data assimilation system. Quart. J. Roy. Meteor. Soc., 137, 553-597, https://doi.org/10.1002/qj.828.

de Ruijter, W. P. M., A. Biastoch, S. S. Drijfhout, J. R. E. Lutjeharms, R. P. Matano, T. Pichevin, P. J. van Leeuwen, and W. Weijerd, 1999: Indian-Atlantic interocean exchange: Dynamics, estimation and impact. J. Geophys. Res., 104, $20885-$ 20 910, https://doi.org/10.1029/1998JC900099.

Drushka, K., J. Sprintall, and S. T. Gille, 2014: Subseasonal variations in salinity and barrier-layer thickness in the eastern equatorial Indian Ocean. J. Geophys. Res. Oceans, 119, 805823, https://doi.org/10.1002/2013JC009422.

Du, Y., Y. Zhang, M. Feng, T. Wang, N. Zhang, and S. Wijffels, 2015: Decadal trends of the upper ocean salinity in the tropical Indo-Pacific since mid-1990s. Sci. Rep., 5, 16050, https:// doi.org/10.1038/SREP16050.

Durack, P. J., and S. E. Wijffels, 2010: Fifty-year trends in global ocean salinities and their relationship to broad-scale 
warming. J. Climate, 23, 4342-4362, https://doi.org/10.1175/ 2010JCLI3377.1.

_ _ _ , and R. J. Matear, 2012: Ocean salinities reveal strong global water cycle intensification during 1950 to 2000. Science, 336, 455-458, https://doi.org/10.1126/science.1212222.

Entekhabi, D., and Coauthors, 2010: The Soil Moisture Active Passive (SMAP) Mission. Proc. IEEE, 98, 704-716, https:// doi.org/10.1109/JPROC.2010.2043918.

Felton, C. S., B. Subrahmanyam, V. S. N. Murty, and J. F. Shriver, 2014: Estimation of the barrier layer thickness in the Indian Ocean using Aquarius salinity. J. Geophys. Res. Oceans, 119, 4200-4213, https://doi.org/10.1002/2013JC009759.

Feng, M., A. Biastoch, C. Böning, N. Caputi, and G. Meyers, 2008: Seasonal and interannual variations of upper ocean heat balance off the west coast of Australia. J. Geophys. Res., 113, C12025, https://doi.org/10.1029/2008JC004908.

— M. J. McPhaden, S.-P. Xie, and J. Hafner, 2013: La Niña forces unprecedented Leeuwin Current warming in 2011. Sci. Rep., 3, 1277, https://doi.org/10.1038/srep01277.

_ J. Benthuysen, N. Zhang, and D. Slawinski, 2015: Freshening anomalies in the Indonesian Throughflow and impacts on the Leeuwin Current during 2010-2011. Geophys. Res. Lett., 42, 8555-8562, https://doi.org/10.1002/2015GL065848.

Forget, G., J. M. Campin, P. Heimbach, C. N. Hill, R. M. Ponte, and C. Wunsch, 2015: ECCO version 4: An integrated framework for non-linear inverse modeling and global ocean state estimation. Geosci. Model Dev., 8, 3071-3104, https://doi.org/ 10.5194/gmd-8-3071-2015.

,,,,---- - - and $\longrightarrow, 2016$ : ECCO version 4: Second release, http://hdl.handle.net/1721.1/102062.

Fukumori, I., O. Wang, I. Fenty, G. Forget, P. Heimbach, and R. M. Ponte, 2017: ECCO version 4 release 3. 10 pp., http:// hdl.handle.net/1721.1/110380.

Giglio, D., and D. Roemmich, 2014: Climatological monthly heat and freshwater flux estimates on a global scale from Argo. J. Geophys. Res. Oceans, 119, 6884-6899, https://doi.org/ 10.1002/2014JC010083.

Gordon, A. L., 2001: Interocean exchange. Ocean Circulation and Climate Observing and Modelling the Global Ocean, G. Siedler, J. Church, and J. Gould, Eds., Academic Press, 303-314. , R. D. Susanto, and K. Vranes, 2003: Cool Indonesian Throughflow as a consequence of restricted surface layer flow. Nature, 425, 824-828, https://doi.org/10.1038/nature02038.

_ C. F. Giulivi, J. Busecke, and F. M. Bingham, 2015: Differences among subtropical surface salinity patterns. Oceanography, 28, 32-39, https://doi.org/10.5670/oceanog.2015.02.

Gray, A. R., and S. C. Riser, 2014: A global analysis of Sverdrup balance using absolute geostrophic velocities from Argo. J. Phys. Oceanogr., 44, 1213-1229, https://doi.org/10.1175/ JPO-D-12-0206.1.

Guan, C., and M. J. McPhaden, 2016: Ocean processes affecting the twenty-first-century shift in ENSO SST variability. J. Climate, 29, 6861-6879, https://doi.org/10.1175/JCLI-D-15-0870.1.

Han, W., and J. P. McCreary, 2001: Modeling salinity distributions in the Indian Ocean. J. Geophys. Res., 106, 859-877, https:// doi.org/10.1029/2000JC000316.

— J. Jialard, M. J. McPhaden, T. Lee, Y. Masumoto, M. Feng, and W. P. M. de Ruijter, 2014: Indian Ocean decadal variability: A review. Bull. Amer. Meteor. Soc., 95, 1679-1703, https://doi.org/10.1175/BAMS-D-13-00028.1.

Hu, D., and Coauthors, 2011: Northwestern Pacific Ocean Circulation and Climate Experiment (NPOCE) Science/ Implementation Plan. China Ocean Press, 100 pp.
$\mathrm{Hu}, \mathrm{S}$., and J. Sprintall, 2016: Interannual variability of the Indonesian Throughflow: The salinity effect. J. Geophys. Res. Oceans, 121, 2596-2615, https://doi.org/10.1002/2015JC011495.

$\longrightarrow$, and —, 2017a: Observed strengthening of interbasin exchange via the Indonesian seas due to rainfall intensification. Geophys. Res. Lett., 44, 1448-1456, https://doi.org/10.1002/ 2016 GL072494.

$\longrightarrow$, and — 2017b: A stronger Indonesian Throughflow related to enhanced regional rainfall. CLIVAR Exchanges, No. 71, International CLIVAR Project Office, Southampton, United Kingdom, 21-25, http://www.clivar.org/sites/default/files/documents/ CE_No_71_Final.pdf.

Jensen, T. G., H. W. Wijesekera, E. S. Nyadjro, P. G. Thoppil, J. F. Shriver, K. K. Sandeep, and V. Pant, 2016: Modeling salinity exchanges between the equatorial Indian Ocean and the Bay of Bengal. Oceanography, 29, 92-101, https://doi.org/10.5670/ oceanog.2016.42.

Kerr, Y. H., P. Waldteufel, J. Wigneron, J. Martinuzzi, J. Font, and M. Berger, 2001: Soil moisture retrieval from space: The Soil Moisture and Ocean Salinity (SMOS) mission. IEEE Trans. Geosci. Remote Sens., 39, 1729-1735, https://doi.org/10.1109/ 36.942551.

Kido, S., and T. Tozuka, 2017: Salinity variability associated with the positive Indian Ocean dipole and its impact on the upper ocean temperature. J. Climate, 30, 7885-7907, https://doi.org/ 10.1175/JCLI-D-17-0133.1.

Lagerloef, G., and Coauthors, 2008: The Aquarius/SAC-D mission: Designed to meet the salinity remote-sensing challenge. Oceanography, 21, 68-81, https://doi.org/10.5670/oceanog.2008.68.

Lago, V., S. E. Wijffels, P. J. Durack, J. A. Church, N. L. Bindoff, and S. J. Marsland, 2016: Simulating the role of surface forcing on observed multidecadal upper-ocean salinity changes. J. Climate, 29, 5575-5588, https://doi.org/10.1175/JCLI-D-15-0519.1.

Lee, T., I. Fukumori, and B. Tang, 2004: Temperature advection: Internal versus external processes. J. Phys. Oceanogr., 34, 1936-1944, https://doi.org/10.1175/1520-0485(2004)034<1936: TAIVEP $>2.0 . \mathrm{CO} ; 2$.

Li, Y., W. Han, and T. Lee, 2015: Intraseasonal sea surface salinity variability in the equatorial Indo-Pacific Ocean induced by Madden-Julian oscillations. J. Geophys. Res. Oceans, 120, 2233-2258, https://doi.org/10.1002/2014JC010647.

Llovel, W., and T. Lee, 2015: Importance and origin of halosteric contribution to sea level change in the southeast Indian Ocean during 2005-2013. Geophys. Res. Lett., 42, 1148-1157, https:// doi.org/10.1002/2014GL062611.

Marshall, J., A. Adcroft, C. Hill, L. Perelman, and C. Heisey, 1997a: A finite-volume, incompressible Navier Stokes model for studies of the ocean on parallel computers. J. Geophys. Res. Oceans, 102, 5753-5766, https://doi.org/10.1029/96JC02775.

— C. Hill, L. Perelman, and A. Adcroft, 1997b: Hydrostatic, quasi-hydrostatic, and nonhydrostatic ocean modeling. J. Geophys. Res. Oceans, 102, 5733-5752, https://doi.org/ 10.1029/96JC02776.

McPhaden, M. J., and Coauthors, 2009: RAMA: The Research Moored Array for African-Asian-Australian Monsoon Analysis and Prediction. Bull. Amer. Meteor. Soc., 90, 459480, https://doi.org/10.1175/2008BAMS2608.1.

Menezes, V. V., M. L. Vianna, and H. E. Phillips, 2014: Aquarius sea surface salinity in the South Indian Ocean: Revealing annual-period planetary waves. J. Geophys. Res. Oceans, 119, 3883-3908, https://doi.org/10.1002/2014JC009935.

Moon, J.-H., and Y. T. Song, 2014: Seasonal salinity stratifications in the near-surface layer from Aquarius, Argo, and an 
ocean model: Focusing on the tropical Atlantic/Indian Oceans. J. Geophys. Res. Oceans, 119, 6066-6077, https://doi.org/10.1002/ 2014JC009969.

Nagura, M., and S. Kouketsu, 2018: Spiciness anomalies in the upper south Indian Ocean. J. Phys. Oceanogr., 48, 2081-2101, https://doi.org/10.1175/JPO-D-18-0050.1.

Nyadjro, E. S., and B. Subrahmanyam, 2016: Spatial and temporal variability of central Indian Ocean salinity fronts observed by SMOS. Remote Sens. Environ., 180, 146-153, https://doi.org/ 10.1016/j.rse.2016.02.049.

Phillips, H. E., S. E. Wijffels, and M. Feng, 2005: Interannual variability in the freshwater content of the Indonesian-Australian Basin. Geophys. Res. Lett., 32, L03603, https://doi.org/10.1029/ 2004 GL021755.

Piola, A. R., and A. Gordon, 1984: Pacific and Indian Ocean upperlayer salinity budget. J. Phys. Oceanogr., 14, 747-753, https:// doi.org/10.1175/1520-0485(1984)014<0747:PAIOUL > 2.0.CO;2.

Ponte, R. M., and N. T. Vinogradova, 2016: An assessment of basic processes controlling mean surface salinity over the global ocean. Geophys. Res. Lett., 43, 7052-7058, https://doi.org/ 10.1002/2016GL069857.

Potemra, J. T., R. Lukas, and G. T. Mitchum, 1997: Large-scale estimation of transport from the Pacific to the Indian Ocean. J. Geophys. Res. Oceans, 102, 27 795-27 812, https://doi.org/ 10.1029/97JC01719.

Rao, R. R., and R. Sivakumar, 2003: Seasonal variability of sea surface salinity and salt budget of the mixed layer of the north Indian Ocean. J. Geophys. Res., 108, 3009, https://doi.org/ 10.1029/2001JC000907.

Roemmich, D., and J. Gilson, 2009: The 2004-2008 mean and annual cycle of temperature, salinity, and steric height in the global ocean from the Argo Program. Prog. Oceanogr., 82, $81-$ 100, https://doi.org/10.1016/j.pocean.2009.03.004.

_ - and Coauthors, 1998: On the design and implementation of Argo: An initial plan for a global array of profiling floats. International CLIVAR Project Office Rep. 21, GODAE Rep. 5, GODAE International Project Office, 32 pp., www.argo.ucsd.edu/argodesign.pdf.

Saji, N., B. N. Goswami, P. Vinayachandran, and T. Yamagata, 1999: A dipole mode in the tropical Indian Ocean. Nature, 401, 360-363, https://doi.org/10.1038/43854.

Song, Q., A. L. Gordon, and M. Visbeck, 2004: Spreading of the Indonesian Throughflow in the Indian Ocean. J. Phys. Oceanogr., 34, 772-792, https://doi.org/10.1175/1520-0485 (2004)034<0772:SOTITI $>2.0 . C O ; 2$.

Sprintall, J., and M. Tomczak, 1992: Evidence of the barrier layer in the surface layer of the tropics. J. Geophys. Res., 97, 73057316, https://doi.org/10.1029/92JC00407.
Thompson, B., C. Gnanaseelan, and P. S. Salvekar, 2006: Variability in the Indian Ocean circulation and salinity and its impact on SST anomalies during dipole events. J. Mar. Res., 64, 853-880, https:// doi.org/10.1357/002224006779698350.

Vinogradova, N., and Coauthors, 2019: Satellite Salinity Observing System: Recent discoveries and the way forward. Front. Mar. Sci., 6, 243, https://doi.org/10.3389/fmars.2019.00243.

Wong, A. P. S., N. L. Bindoff, and J. A. Church, 1999: Largescale freshening of intermediate waters in the Pacific and Indian Oceans. Nature, 400, 440-443, https://doi.org/ $10.1038 / 22733$.

— , and Coauthers, 2019: Argo quality control manual for CTD and trajectory data. Version 3.2, 59 pp., https://doi.org/ $10.13155 / 33951$.

Wunsch, C., and P. Heimbach, 2007: Practical global oceanic state estimation. Physica D, 230, 197-208, https://doi.org/10.1016/ j.physd.2006.09.040.

— global ocean circulation and ice state estimates. Ocean Circulation and Climate: A 21 Century Perspective, G. Siedler et al., Eds., International Geophysics Series, Vol. 103, Academic Press, 553-579.

- and Coauthors, 2009: The global general circulation of the ocean estimated by the ECCO-Consortium. Oceanography, 22, 88-103, https://doi.org/10.5670/oceanog.2009.41.

Wyrtki, K., 1987: Indonesian through flow and the associated pressure gradient. J. Geophys. Res., 92, 12 941-12 946, https:// doi.org/10.1029/JC092IC12P12941.

Yu, L., X. Jin, and R. Weller, 2008: Multidecade Global Flux Datasets from the Objectively Analyzed Air-Sea Fluxes (OAFlux) Project: Latent and sensible heat fluxes, ocean evaporation, and related surface meteorological variables. OAFlux Project Tech. Rep. OA-2008-01, 64 pp., oaflux.whoi.edu/pdfs/OAFlux_TechReport_3rd_release.pdf.

Zhang, N., M. Feng, Y. Du, J. Lan, and S. E. Wijffels, 2016: Seasonal and interannual variations of mixed layer salinity in the southeast tropical Indian Ocean. J. Geophys. Res. Oceans, 121, 4716-4731, https://doi.org/10.1002/ 2016JC011854

Zhang, Y., Y. Du, S. Zheng, Y. Yang, and X. Cheng, 2013: Impact of Indian Ocean dipole on the salinity budget in the equatorial Indian Ocean. J. Geophys. Res. Oceans, 118, 4911-4923, https://doi.org/10.1002/jgrc.20392.

, M. Feng, Y. Du, H. E. Phillips, N. L. Bindoff, and M. J. McPhaden, 2018: Strengthened Indonesian Throughflow drives decadal warming in the southern Indian Ocean. Geophys. Res. Lett., 45, 6167-6175, https://doi.org/10.1029/ 2018GL078265. 